\title{
The Vital Capacity of the Lungs of Children in Health and Disease
}

\author{
A THESIS \\ SUBMITTED TO THE FACULTY OF THE GRADUATE SCHOOI. \\ OF THE UNIVERSITY OF MINNESOTA
}

IN PARTIAL FULFILLMENT OF THE REQUIREMENTS FOR THE DEGREE OF

DOCTOR OF PHILOSOPHY

1921

CHESTER A. STEWART, M.D., PH.D

Assistant Professor of Pediatrics, University of Minnesota MINNEAPOLIS 
THE VITAL CAPACITY OF THE LUNGS OF CHILDREN IN HEALTH AND DISEASE*

\author{
CHESTER A. STEWART, M.D., PH.D. \\ Assistant Professor of Pediatrics, University of Minnesota. \\ MINNEAPOLIS
}

As a result of recent investigations, the clinical value of the determination of vital capacity in diseases of the heart and lungs has attracted attention, especially since this measurement is often found to be greatly reduced by various pathologic conditions of these organs. It has long been recognized, however, that in order for the determination of the vital capacity to be of any great practical value, it is necessary, first, to determine the normal relationship existing between it and other body measurements. Investigators, therefore, have attempted to establish normal standards for vital capacity based on age, height, body weight, stem length, trunk volume and surface area, but in most instances have neglected to determine the extent of normal variability. Since for any body measurement the lung capacity is known to show a certain amount of variability, it is clear that in order to detect abnormal fluctuations, the extent of normal variability must be determined first. Therefore, in connection with the study of vital capacity for children, an attempt is made to estimate the extent of normal variability during childhood. I am indebted to Drs. R. E. Scammon and Wm. Hart for valuable advice concerning the statistical treatment of the data presented in this paper.

1. Material and Methods.-Observations are reported for 2,509 normal and healthy children, 1,289 boys and 1,220 girls, ranging in age between 4 and 19 years inclusive. The data (sexes separated) are averaged according to age in Tables 1 and 2 , according to standing height in Tables 3, 4, 5 and 6 , according to sitting height in Tables 7, 8, 9 and 10, and finally according to body weight in Tables 11 and 12 . In addition, observations are recorded for fourteen boys and twenty-six girls (Table 13) afflicted with mitral insufficiency of varying degrees of severity; for seventeen boys and fourteen girls (Table 14) suffering from acute bronchitis; for four boys and five girls (Table 15) with pneumonia; for thirteen boys and four girls (Table 16) subject to asthma; and lastly for seventy-nine boys and seventy-one girls (Tables

If 17 and 18) having tuberculosis. The total of all the observations for

- vital capacity, including both the normal and also the pathologic cases, amounts to 1,420 with the boys and 1,342 with the girls, a grand total of 2,762 cases. 
The vital capacity was measured by means of an accurately calibrated wet spirometer, which offered very little resistance to expiration. The children were carefully instructed to take the deepest possible inspiration, and to empty the lungs completely into the spirometer. As a rule, small groups were taken at a time, so each subject understood from observation how to cooperate to the best advantage. Every child was permitted several trials, and the maximum repeatedly expired was recorded as the vital capacity. The children were urged to do their best, and usually the spirit of competition was sufficiently keen to make one reasonably certain that the records obtained represent the best effort they were capable of exerting. In instances where the cooperation of the child was unsatisfactory, the data were discarded. Furthermore, children having an unusually low vital capacity were included in the averages only in case they gave no history of chronic heart or lung disease. So far as possible all children suffering from acute respiratory infections were excluded from the averages. The vital capacities recorded are not corrected for temperature, aqueous vapor tension, or for variations in barometric pressure.

The children were weighed wearing their ordinary indoor winter clothing. In order to obtain the net weight, the weight of the clothing (computed as recommended by Bardeen ${ }^{1}$ ) is deducted from the observed gross weight. The standing height (in stocking feet), and also the sitting height (measured with the children seated against a perpendicular scale) was recorded for each child in the majority of instances.

In the analysis of the data for the normal children, as averaged according to age, standing height, and stem length, in each case statistical methods are employed to calculate the degree each average might be expected to fluctuate were observations obtainable upon an infinitely large number of comparable series of cases, and also to determine the extent of absolute and relative variability of vital capacity, by the estimating of the probable error, the standard deviation, and by computing the coefficients of variation, respectively.

The possibility of deriving the approximate normal vital capacity by the estimating of the probable error, the standard deviation, and for any known age, standing height, sitting height, or weight, by means of empirical formula is discussed later on.

2. Vital Capacity and Age.-The averages for the vital capacity of the lungs at different ages, as estimated from the nearest birth day,

1. Bardeen, C. R.: Weight for Height charts for school boys and girls, Bull. Univ. Wis. Beyer: Growth of U. S. Naval Cadets, Proc. U. S. Naval Inst. 21, 1895. 
are recorded in Tables 1 and 2. Since there is a sexual difference in vital capacity at corresponding ages, the data for the boys and girls are averaged separately in the tables. In most instances the number of subjects in each group is sufficiently large to render the means fairly significant, especially for the boys from 6 to 16 years, inclusive, and for the girls from 6 to 15 years. For the other groups the averages recorded are probably of less significance, due to the fact that they include relatively fewer observations.

Between 6 and 16 years of age, inclusive, the average vital capacity of the lungs with the boys (Table 1) shows an increase from 1,154 to 3,425 c.c., the absolute gain during the ten years amounting to 2,271 c.c. When expressed in terms of relative increase, this gain amounts to about 197 per cent. Consequently, at 16 years of age the average vital capacity for the boys is practically three times as great as the initial value at 6 years.

With the girls between 6 and 16 years of age, inclusive (Table 2), the average vital capacity increases from 1,085 to 2,778 c.c. The absolute gain in this case amounts to 1,693 c.c., or approximately 578 c.c. less than the increase registered by the boys during a similar period. The relative increase for the ten years amounts to approximately 156 per cent. with the girls, as compared with 197 per cent. gain for the boys. Consequently, at 16 years of age the vital capacity with the girls is only two and one-half times as great as the initial 6 year average.

As is true of physical measurements in general, the vital capacity likewise fluctuates within rather wide limits. Thus, at practically each age the maximum vital capacity recorded (Tables 1 and 2 ) is two or more times as large as the minimum observed. On inspecting the individual data, however, it is found that in many cases these extreme variations in lung capacity at each age, paralleled to some extent the individual's variation in size from the average of his respective groups. Thus, the unusually low vital capacities recorded, were obtained, as a rule, from children considerably below the average size for their age, whereas the maximum readings were usually for children considerably larger than their group average. The absolute extent of the variation becomes larger as the vital capacity increases, and also is usually greater for the boys than for the girls of corresponding age. Although absolute variability evidently increases with age, and differs for each sex, it does not necessarily follow that relative variability obeys the same rule. In order to determine the degree of relative variability in vital capacity at different ages, and for each sex, it is necessary to resort to methods of statistical analysis of the data. This is attempted in a succeeding paragraph. 
table 1.-Normal Boys. Age, Number of Cases, Average Standing Height, Average and Range of Vital. Capacity, Mean Vital. Ciplor

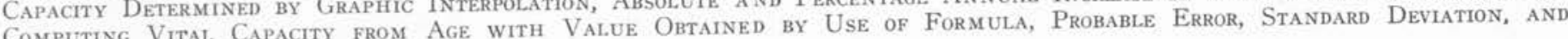
COEFFICIENT OF VARIATION

\begin{tabular}{|c|c|c|c|c|c|c|c|c|c|c|c|c|c|}
\hline $\begin{array}{l}\text { Age in } \\
\text { Years }\end{array}$ & $\begin{array}{l}\text { No. of } \\
\text { Cases }\end{array}$ & $\begin{array}{l}\text { Standing } \\
\text { Height, } \\
\text { Cm. }\end{array}$ & $\begin{array}{l}\text { Average } \\
\text { Vital } \\
\text { Capacity, } \\
\text { O.e. }\end{array}$ & $\begin{array}{l}\text { Minimum } \\
\text { Vital } \\
\text { Capacity, } \\
\text { C.c. }\end{array}$ & $\begin{array}{l}\text { Maximum } \\
\text { Vital } \\
\text { Capacity, } \\
\text { C.e. }\end{array}$ & $\begin{array}{l}\text { Mean V. C. } \\
\text { Determined } \\
\text { by Graphie } \\
\text { Interpola- } \\
\text { tion, C.c. } \\
\end{array}$ & $\begin{array}{l}\text { Absolute } \\
\text { Annual } \\
\text { Inerease } \\
\text { in V. C., } \\
\text { C.c. } \\
\end{array}$ & $\begin{array}{c}\text { Percentage } \\
\text { Yearly } \\
\text { Inerease } \\
\text { in Vital } \\
\text { Capacity } \\
\end{array}$ & $\begin{array}{c}\text { V. C. as } \\
\text { Computed } \\
\text { by Formula } \\
y=(a x) \pm b \\
\text { C.e. }\end{array}$ & $\begin{array}{c}\text { Empirieal Formula } \\
\text { and Values for } \\
\text { Constants Used for } \\
\text { Faeh Age Group } \\
\mathbf{y}=(\mathrm{ax}) \pm \mathrm{b}\end{array}$ & $\begin{array}{c}\text { Probable } \\
\text { Error of } \\
\text { Random } \\
\text { Sampling, } \\
\text { C.e. } \\
\end{array}$ & $\begin{array}{c}\text { Standard } \\
\text { Devia- } \\
\text { tion, } \\
\text { C.e. }\end{array}$ & $\begin{array}{l}\text { Coefficient } \\
\text { of Varia- } \\
\text { tion, } \\
\text { per Cent. }\end{array}$ \\
\hline $\begin{array}{l}4 \\
5 \\
6 \\
7 \\
8 \\
9\end{array}$ & $\begin{array}{r}6 \\
20 \\
62 \\
112 \\
98 \\
110\end{array}$ & $\begin{array}{l}103.4 \\
106.8 \\
112.2 \\
116.9 \\
121.8 \\
129.9\end{array}$ & $\begin{array}{r}792 \\
927 \\
1,154 \\
1,290 \\
1,468 \\
1,715\end{array}$ & $\begin{array}{r}500 \\
600 \\
800 \\
900 \\
1,050 \\
1,200\end{array}$ & $\begin{array}{r}900 \\
1,150 \\
1,600 \\
2,200 \\
2,100 \\
2,300\end{array}$ & $\begin{array}{r}792 \\
958 \\
1,124 \\
1,304 \\
1,491 \\
1,679\end{array}$ & $\begin{array}{l}166 \\
166 \\
180 \\
187 \\
188\end{array}$ & $\begin{array}{r}21.0 \\
17.3 \\
16.0 \\
14.3 \\
2.6\end{array}$ & $\begin{array}{r}791 \\
969 \\
1,146 \\
1,323 \\
1,501 \\
1,679 \\
\end{array}$ & $\begin{array}{l}\mathrm{y} \equiv \mathrm{V} \cdot \mathrm{C} . \\
\mathrm{a} \equiv \mathrm{Age} \text { in years } \\
\mathrm{x} \equiv 177.5 \\
\mathrm{~b}=+81\end{array}$ & $\begin{array}{l}15.6 \\
12.3 \\
15.0 \\
15.8\end{array}$ & $\begin{array}{l}182 \\
194 \\
220 \\
246\end{array}$ & $\begin{array}{l}15.8 \\
15.0 \\
15.0 \\
14.8\end{array}$ \\
\hline $\begin{array}{l}10 \\
11 \\
12\end{array}$ & $\begin{array}{r}87 \\
113 \\
114\end{array}$ & $\begin{array}{l}133.4 \\
137.8 \\
142.4\end{array}$ & $\begin{array}{l}1,872 \\
1,991 \\
2,182\end{array}$ & $\begin{array}{l}1,400 \\
1,300 \\
1,300\end{array}$ & $\begin{array}{l}2,650 \\
2,800 \\
3,300\end{array}$ & $\begin{array}{l}1,859 \\
2,015 \\
2,210\end{array}$ & $\begin{array}{l}180 \\
156 \\
195\end{array}$ & $\begin{array}{l}10.7 \\
8.2 \\
9.0\end{array}$ & $\begin{array}{l}1,856 \\
2,034 \\
2,212 \\
\end{array}$ & $\begin{array}{l}\mathrm{y}=\mathrm{V} . \mathrm{C} \text {. } \\
\mathrm{a} \equiv \text { Age in years } \\
\mathrm{x} \equiv 178.0 \quad \mathrm{~b}=+76\end{array}$ & $\begin{array}{l}18.9 \\
17.1 \\
21.5\end{array}$ & $\begin{array}{l}262 \\
270 \\
340\end{array}$ & $\begin{array}{l}14.0 \\
13.6 \\
15.6\end{array}$ \\
\hline $\begin{array}{l}13 \\
14 \\
15 \\
16 \\
17 \\
18 \\
19\end{array}$ & $\begin{array}{r}132 \\
177 \\
155 \\
67 \\
23 \\
9 \\
4\end{array}$ & $\begin{array}{l}148.7 \\
154.8 \\
159.9 \\
167.2 \\
17.4 \\
17.0 \\
168.2\end{array}$ & $\begin{array}{l}2,458 \\
2,712 \\
3,145 \\
3,425 \\
3,776 \\
3,922 \\
4,300\end{array}$ & $\begin{array}{l}1,700 \\
1,400 \\
1,850 \\
2,100 \\
2,400 \\
2,750 \\
4,100\end{array}$ & $\begin{array}{l}4,000 \\
4,300 \\
4,400 \\
4,300 \\
4,500 \\
4,400 \\
4,500\end{array}$ & $\begin{array}{l}2,451 \\
, 2,772 \\
3,094 \\
3,417 \\
3,708 \\
3,999 \\
4,300\end{array}$ & $\begin{array}{l}241 \\
321 \\
322 \\
323 \\
289 \\
281 \\
301\end{array}$ & $\begin{array}{r}10.9 \\
13.1 \\
11.6 \\
10.8 \\
8.5 \\
7.6 \\
7.5\end{array}$ & $\begin{array}{l}2.450 \\
2,760 \\
3.070 \\
3,380 \\
3,690 \\
4,000 \\
4,310\end{array}$ & $\begin{array}{l}\mathrm{y}=\mathrm{V} . \mathrm{C} \\
\mathrm{a} \equiv \mathrm{Age} \text { in years } \\
\mathrm{x} \equiv 310.0 \\
\mathrm{~b}=-1,580\end{array}$ & $\begin{array}{l}25.2 \\
24.5 \\
29.8 \\
47.2\end{array}$ & $\begin{array}{l}430 \\
484 \\
551 \\
573\end{array}$ & $\begin{array}{l}17.5 \\
17.8 \\
17.5 \\
16.7\end{array}$ \\
\hline
\end{tabular}


TABle 2.-Normal Girls. Age, Number of Cases, Average Standing Height, Average and Range of Vital Capacity, Mean Vital Capacity Determined by Graphic Interpolation, Absolute a nd Percentage Annual Increase in Vital Capacity, Formula for Computing Vital Capacity from Age with Values Obtained by Use of formula, Probable Error, Standard Deviation, and COEFFicient OF VARIATION

\begin{tabular}{|c|c|c|c|c|c|c|c|c|c|c|c|c|c|}
\hline $\begin{array}{l}\text { Age in } \\
\text { Years }\end{array}$ & $\begin{array}{l}\text { No. of } \\
\text { Cases }\end{array}$ & $\begin{array}{l}\text { Standing } \\
\text { Height. } \\
\text { Cm. }\end{array}$ & $\begin{array}{l}\text { Average } \\
\text { Vital } \\
\text { Capacity, } \\
\text { C.e. }\end{array}$ & $\begin{array}{c}\text { Minimum } \\
\text { Vital } \\
\text { Capacity, } \\
\text { C.c. }\end{array}$ & $\begin{array}{l}\text { Maximum } \\
\text { Vital } \\
\text { Capacity, } \\
\text { C.e. }\end{array}$ & $\begin{array}{l}\text { Mean V. C. } \\
\text { Determined } \\
\text { by Graphie } \\
\text { Interpola- } \\
\text { tion, C.e. }\end{array}$ & $\begin{array}{c}\text { Absolute } \\
\text { Annual } \\
\text { Increase } \\
\text { in V. C.. } \\
\text { C.e. }\end{array}$ & $\begin{array}{c}\text { Percentage } \\
\text { Yearly } \\
\text { Increase } \\
\text { in Vital } \\
\text { Capacity }\end{array}$ & $\begin{array}{c}\text { V. C. as } \\
\text { Computed } \\
\text { by Formula } \\
y=(a x) \pm b \\
\text { C.e. }\end{array}$ & $\begin{array}{l}\text { Empirieal Formula } \\
\text { and Values for } \\
\text { Constants Used for } \\
\text { Fach Age Group } \\
y=(\mathrm{ax}) \pm \mathrm{b}\end{array}$ & $\begin{array}{l}\text { Probable } \\
\text { Error of } \\
\text { Random } \\
\text { Sampling. } \\
\text { C.e. }\end{array}$ & $\begin{array}{c}\text { Standard } \\
\text { Devia- } \\
\text { tion, } \\
\text { C.e. }\end{array}$ & $\begin{array}{l}\text { Coefficient } \\
\text { of Varia- } \\
\text { tion, } \\
\text { per Cent. }\end{array}$ \\
\hline $\begin{array}{r}4 \\
5 \\
6 \\
7 \\
8 \\
9 \\
9 \\
10 \\
11\end{array}$ & $\begin{array}{r}9 \\
26 \\
62 \\
81 \\
76 \\
73 \\
117 \\
119\end{array}$ & $\begin{array}{r}95.4 \\
106.4 \\
111.5 \\
114.4 \\
112.0 \\
127.0 \\
132.1 \\
135.9\end{array}$ & $\begin{array}{r}664 \\
888 \\
1,085 \\
1,228 \\
1,401 \\
1,513 \\
1,672 \\
1,799\end{array}$ & $\begin{array}{r}350 \\
600 \\
700 \\
900 \\
800 \\
1,000 \\
900 \\
1,250\end{array}$ & $\begin{array}{r}850 \\
1,200 \\
1,600 \\
1,800 \\
1,950 \\
2,250 \\
2,400 \\
2,550\end{array}$ & $\begin{array}{r}644 \\
852 \\
1,045 \\
1,215 \\
1,373 \\
1,524 \\
1,685 \\
1,871\end{array}$ & $\begin{array}{l}\ddot{208} \\
193 \\
170 \\
158 \\
151 \\
161 \\
186\end{array}$ & $\begin{array}{l}13.3 \\
22.7 \\
16.3 \\
13.0 \\
11.0 \\
10.6 \\
11.0\end{array}$ & $\begin{array}{r}644 \\
819 \\
995 \\
1,170 \\
1,345 \\
1,521 \\
1,696 \\
1,871\end{array}$ & $\begin{array}{l}y=v \cdot C \text {. in } \mathrm{Cm} . \\
\mathrm{a} \equiv \text { Age in years } \\
\mathrm{x}=175.3 \\
\mathrm{~b}=-57\end{array}$ & $\begin{array}{l}14.0 \\
13.6 \\
15.4 \\
18.1 \\
17.0 \\
14.9\end{array}$ & $\begin{array}{l}163 \\
181 \\
199 \\
229 \\
273 \\
241\end{array}$ & $\begin{array}{l}15.0 \\
14.7 \\
13.5 \\
15.1 \\
16.3 \\
13.4\end{array}$ \\
\hline $\begin{array}{l}12 \\
13 \\
14 \\
15 \\
26\end{array}$ & $\begin{array}{r}135 \\
162 \\
192 \\
131 \\
29\end{array}$ & $\begin{array}{l}144.0 \\
151.4 \\
156.6 \\
157.8 \\
160.1\end{array}$ & $\begin{array}{l}2,053 \\
2,349 \\
2,607 \\
2,702 \\
2,778\end{array}$ & $\begin{array}{l}1,400 \\
1,550 \\
1,900 \\
1,900 \\
2,050\end{array}$ & $\begin{array}{l}2,900 \\
3,600 \\
3,800 \\
3,700 \\
3,500\end{array}$ & $\begin{array}{l}2,085 \\
2,300 \\
2,511 \\
2,616 \\
2,817\end{array}$ & $\begin{array}{l}214 \\
224 \\
202 \\
165 \\
141\end{array}$ & $\begin{array}{r}11.4 \\
10.7 \\
8.7 \\
6.6 \\
5.3\end{array}$ & $\begin{array}{l}2,085 \\
2,268 \\
2,451 \\
2,634 \\
2,817\end{array}$ & $\begin{array}{l}y=V . C . \text { in } \mathrm{Cm} . \\
\mathrm{a} \equiv \mathrm{Age} \text { in years } \\
\mathrm{x} \equiv 183.0 \\
\mathrm{~b}=-11\end{array}$ & $\begin{array}{l}19.9 \\
21.7 \\
17.5 \\
24.3\end{array}$ & $\begin{array}{l}343 \\
409 \\
361 \\
413\end{array}$ & $\begin{array}{l}16.7 \\
17.5 \\
13.9 \\
15.3\end{array}$ \\
\hline $\begin{array}{l}17 \\
18\end{array}$ & 7 & $\begin{array}{l}162.6 \\
162.0\end{array}$ & $\begin{array}{l}2,943 \\
3,100\end{array}$ & $\begin{array}{l}2,250 \\
\ldots . .\end{array}$ & $\begin{array}{l}3,400 \\
\ldots \ldots .\end{array}$ & $\begin{array}{l}2,965 \\
3,100\end{array}$ & $\begin{array}{l}138 \\
145\end{array}$ & $\begin{array}{l}4.9 \\
4.9\end{array}$ & $\begin{array}{l}2,958 \\
3,100\end{array}$ & $\begin{array}{l}\mathrm{y}=\mathrm{V} \cdot \mathrm{C} \cdot \text {. in } \mathrm{Cm} . \\
\mathrm{a} \equiv \mathrm{Age} \text { in years } \\
\mathrm{x} \equiv 141.2 \\
\mathrm{~b}=+558\end{array}$ & & & \\
\hline
\end{tabular}


The general trend of the increase in the average vital capacity of the lungs with advancing age is shown graphically in Figure 1. In order to eliminate minor fluctuations the curves have been smoothed by means of graphic interpolation. This produces a curve which probably conforms more exactly with the type of curve that would be obtained from averages based upon an infinitely large number of cases, and probably represents more nearly the true mean vital capacity. The mean vital capacity at each age, as determined by graphic interpolation, is recorded in Tables 1 and 2, and represented in graphic form in Figure 1. The actual averages for the vital capacity are represented in the figure by dots for the boys and by circles for the girls. In general,

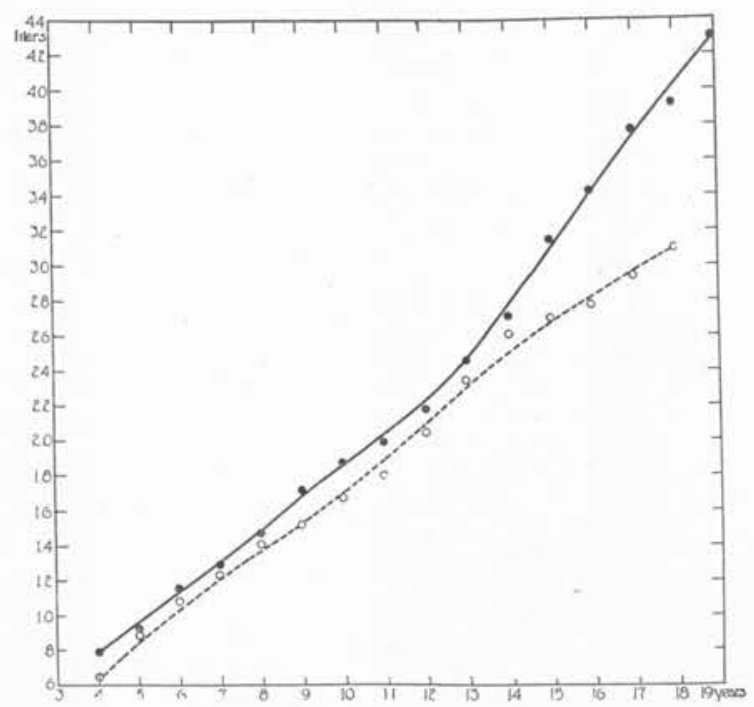

Fig. 1.-Showing smoothed curves representing the average absolute increase in the vital capacity of the lungs as determined by graphic interpolation, for boys between 4 and 19 years of age inclusive, and for girls between 4 and 18 years of age inclusive. The actual averages at each age for the boys are represented by dots and by circles for the girls. Vital capacity in liters is represented on the ordinate, and age in years on the abscissa. The solid line represents the boys; the broken line the girls in this and Figures 2, 3 and 4.

the smoothed curve of vital capacity for each sex tends to assume a concave form corresponding closely with the curve based on the actual averages. From 4 to 11 years, inclusive, the curve for boys is practically a straight line, due to the fair uniformity of the yearly increase in vital capacity. This is followed later by a period of acceleration reaching a maximum at 14 years, which apparently is fairly well maintained, although at a reduced rate, at least until 19. This accounts largely for the general concavity of the curve. 
There appear, therefore, to be three main phases in the curve representing the increase in vital capacity for the boys between 4 and 19 years: (1) a period of fairly uniform increase between 4 and 10 ; (2) a period of acceleration extending from 12 to 14 , and (3) a period of uniform but less rapid increase in vital capacity to 19 .

The smoothed curve of vital capacity (Fig. 1) for the girls likewise shows several phases. Between 4 and 6 years of age the curve rises rather abruptly. From 7 to 10 the annual increase in vital capacity is fairly uniform but slower than during the earlier period. An acceleration in the rate of increase occurs at 11 and persists until 13. Due, in part, to the failure of this rapid yearly increase in vital capacity to continue during the following five years, the concavity produced by the prepubertal acceleration in the curve of vital capacity as plotted against age is much less marked for the girls than for the boys, and also does not extend over as great a period of years as with the former.

The accelerated increase in vital capacity appearing at 11 and 12 years of age for the girls and boys, respectively, is, no doubt, related to the normal prepubertal acceleration of the growth of the body as a whole.

The difference in vital capacity between girls and boys at corresponding ages, is clearly shown by the curves in Figure 1. Throughout the period studied the boys have the larger lung capacity. At 6 years the difference amounts to approximately 79 c.c., which at 10 years has increased to 174 c.c. Subsequently the girls show a more rapid increase in vital capacity which reduces the difference to 125 c.c. at 12 years of age. From the fourteenth year on, the difference in vital capacity between the two sexes, rapidly increases.

As long ago as 1854 Wintrich $^{2}$ noted the existence of a sexual difference in the vital capacity of the lungs, and observed that this difference persists until old age. Since then this observation has been confirmed frequently by practically all investigators who have studied the subject. Among the more recent and extensive observations on children, the data collected by Gilbert, ${ }^{3}$ for 1,279 boys and 1,244 girls, and also Smedley's ${ }^{4}$ averages for 2,788 boys and 3,471 girls, show the vital capacity at all ages to be larger for the boys. Baldwin ${ }^{5}$ apparently

2. Wintrich, M. A.: Einteilung zur Darstellung der Krankheiten der Respirations organe. Virchow, R.: Handbuch der speciellen Pathologie u. Therap. $\mathbf{9 2}, 1854$.

3. Gilbert, J. A.: Researches on the Mental and Physical Development of School Children. Studies from Yale Psychological Laboratory, 2, 1894. Researches on School Children and College Students. University of Iowa Studies in Psychology. 1, 1897.

4. Smedley, F. W.: Report of Commissioner of Education 1, 1902.

5. Baldwin, B. T.: Physical Growth and School Progress, U. S. Bureau of Education Bull. No. 10. The Normal Child. Its Physical Growth and Mental Development, Pop. Sc. Monthly 85, 1914. 
is the only one who has obtained different results. He states that boys have a greater lung capacity on the average than the girls, except between 13 and 14 years of age when just the reverse is true. My own data indicate a larger vital capacity for the boys at all ages, and thus are in agreement with the findings of Gilbert, Smedley and others.

The absolute yearly increase in vital capacity for the boys (Table 1) is fairly uniform until 10 years of age, but at the eleventh year the increase is considerably lower than that registered at any other time. Following this period of retardation, the absolute annual growth in vital capacity becomes accelerated and until 19 years maintains a more rapid rise than occurs at any earlier age.

With the girls the average absolute annual increase in vital capacity (Table 2) also is fairly uniform between 6 and 10 years of age. Starting at 11 years (one year earlier than noted with the boys), the absolute annual increase becomes accelerated, but is maintained only until the fifteenth year; whereas with the boys the vital capacity continues to grow rapidly until 19 years of age. This results on a marked divergence at the period between the curves for vital capacity for the two sexes when plotted against age. The greatest annual gain in vital capacity amounted to 323 c.c. for the boys during the fifteenth year, as compared with a smaller maximum of 224 c.c. for the girls at 13 years of age.

A consideration of the percentage annual increase in vital capacity gives one a conception of the relative rapidity of growth in this respect at different ages. With the boys the rate of relative increase diminishes rapidly from an average annual gain between 4 and 5 years of 21 per cent., to a minimum rate of 8.2 per cent. at 11 years of age. During the following three years, the rate of growth of lung capacity becomes relatively more rapid, rising to 13.1 per cent. at 14 years, but later steadily declines.

With the girls the relative increase in vital capacity decreases from 32.3 to 10.6 per cent. between 5 and 10 years inclusive. During the following two years the rate of annual growth becomes more rapid, amounting to 11.4 per cent. at 12 years as compared with a rise to 13.1 per cent. for the boys at 14. Following this period of acceleration, the rate of increase in lung capacity diminishes rapidly.

In general, then, for each sex the relative rate of annual growth in vital capacity shows a tendency to decrease during early childhood, becomes slightly more rapid about the time of the advent of puberty, and later gradually declines. The period of acceleration in the rate of lung capacity growth begins and terminates at an earlier age with the girls than with the boys.

The data published by Smedley, ${ }^{4}$ which are the most extensive series of observations on children at present available in the literature, like- 
wise show that the rate of annual increase in vital capacity diminishes during early childhood, rises about the time of puberty and later declines. His averages also indicate that the prepubertal acceleration appears later, and is relatively greater with the boys than with the girls.

If we now return to a consideration of the smoothed curves of vital capacity as plotted against age (Fig. 1) it is found possible to divide the curve for each sex into three phases, so selected that each segment conforms closely to straight lines of different incliniation. Thus for the boys the portions of the curve between 4 and 9 years, between 10 and 12 years, and between 13 and 19 years deviate but slightly from the straight lines connecting these various points. Likewise, with the girls the successive segments from 4 to 11,12 to 14 , and 15 to 18 years of age, inclusive, also conform rather closely to the different straight lines drawn through these points.

The value of any point upon a straight line may be readily determined by means of the empirical formula $y=a x \pm b$, where $y=$ the unknown value, $\mathrm{a}=\mathrm{a}$ known variable, $\mathrm{x}=\mathrm{a}$ constant, and $\mathrm{b}=\mathrm{a}$ second constant. It follows, therefore, that the vital capacity between successive segments of the curve conforming closely to a straight line may be determined in a fairly satisfactory and accurate manner by employing the above formula where $\mathrm{y}=$ the vital capacity to c.c., $a=$ the age in years, $\mathrm{x}=\mathrm{a}$ constant, and $\pm \mathrm{b}=\mathrm{a}$ second constant. The vital capacity as derived by formula, and also the different values for the constants $\mathrm{x}$ and $\mathrm{b}$ are given in Tables 1 and 2 . On inspecting the data the computed vital capacities are found to agree rather closely with the means as determined by graphic interpolation. With the boys the greatest difference occurs at 16 years where value derived by formula is 37 c.c. too low. For the girls the greatest deviation amounts to 60 c.c. at 14 years. Evidently, therefore, the vital capacity of the lungs for each between certain ages, may be derived with fair accuracy by means of a simple straight line formula.

The necessity of establishing some relationship between the vital capacity of the lungs and other body measurements in order to be of any practical clinical value has long been recognized. In 1846 Hutchinson, ${ }^{\circ}$ by inventing the spirometer, was the first to obtain extensive and accurate records of vital capacity. From this scientific pioneer study Hutchinson concluded that a definite relationship exists to standing height, the vital capacity increasing in a simple arithmetical progression with increase in height. For each additional inch with individuals between 5 and 6 feet tall he states that 8 additional cubic inches of air at $60 \mathrm{~F}$. may be given out by a forced expiration. Hutchinson also

6. Hutchinson, J.: On the Capacity of the Lungs and on the Respiratory Functions, Med. chir. Tr. 29, 1846, Lancet 1. 1846. 
recognized that weight, age and sex might modify averages to some extent, but believed, however, that no definite relationship existed between vital capacity and either the body weight, the sitting height, or the chest circumference.

Fabius ${ }^{7}$ pointed out the occurrence of marked individual variation from averages based on height. He asserted that the vital capacity divided by the product of of the stem length (measured from the external accipital protuberance to the tip of the $\operatorname{coccyx}$ ) and the chest circumference produced a constant which varied only a slight extent with different individuals. The cause of this variability in the constant Fabius attributed to differences in age and chest expansion. Fabius emphasized, therefore, that the length, circumference and mobility of the chest should be measured in determining whether or not an individual's vital capacity is normal.

Wintrich ${ }^{2}$ investigated the vital capacity of the lungs of 3,500 healthy persons including 500 women. He noted that during childhood age influenced the vital capacity markedly, and also that a sexual difference persisted into old age. Wintrich was interested mainly in the relationship between vital capacity and height.

Schneevoogt ${ }^{8}$ concluded that standards of vital capacity in relation to age and height are of the most practical value, and claimed that deviations of 500 c.c. from such standards could not be assumed to be necessarily abnormal.

Arnold ${ }^{9}$ found extremes of fluctuations to be greater when comparisons were made on a basis of stem length, rather than on standing height. In discussing the smaller vital capacity of the lungs of women as compared with the men relative to height and chest circumference, Arnold points out that the chest expansion is less for the females than for the males.

From a study of the vital capacity of the lungs of 515 students, Kottelman ${ }^{10}$ observed that the lung capacity increases with age faster than the growth in body length occurs. MacDonald ${ }^{11}$ points out that the data presented by Kottelman also show that weight increases with age more rapidly than increase in lung capacity.

7. Fabius, H.: De spirometro ejusque usu observationibus cum alioum, tum propriis illustrato, Diss. Amsterdam, Ztschr. rationell. Med. 4, 1853.

8. Schneevoogt, G. E. V.: Ztschr. rationelle med. 9, 1854, (cited by Lungsgaard and Van Slyke).

9. Arnold, F.: Ueber die Athmungsgrösse des Menschen, Heidelberg, 1855.

10. Kottelman, L.: Die Körper verhält nisse der gelehrten Schüler des Johannaens in Hamburg, Ztschr. d. Königlch Preussischen statistischen Bureaus, Berlin, 1879.

11. Mac Donald, A, Experimental Study of Children, U. S. Bureau of Education Report of Commisioner 1, 1897. 
The existence of a relationship between vital capacity and weight is disputed by Hall. ${ }^{12}$ This observer arrived at the unique conclusion that the vital capacity varies directly with the strength of the individual.

Bohr ${ }^{13}$ objected to the use of standing height for estimating the normal vital capacity on the grounds that the individual variability is so great as to render this method inapplicable. He maintained that the total and residual air as well as the vital capacity should be determined, and placed greater emphasis upon the percentage relationship between these various subdivisions of the total lung volume, than on their absolute value. Hasselbach, ${ }^{13 a}$ Rubow, ${ }^{14}$ Siebeck, ${ }^{15}$ Bie and Maar $^{16}$ and Plesch ${ }^{17}$ also investigated the relationship between the total lung volume, the middle and vital capacities and the residual air in normal and pathologic conditions, and likewise were interested more in the relative than in the absolute value of the different volumes.

Peabody and Wentworth, ${ }^{18}$ studying the vital capacities for a group of 140 healthy adults (ninety-six males and forty-four females), divided the subjects into three groups according to their height and considered the average vital capacity for each group as a normal standard for corresponding height. Of the ninety-six men, 84 per cent. registered vital capacities falling within 10 per cent. of their respective normal. These same authors, in a study of a small group of cases, have also found a rather close relationship to the body surface area.

Recently Lundsgaard and Van Slyke ${ }^{19}$ have claimed that the vital capacity of the lungs is closely related to the calculated chest volume.

12. Hall, W. S, : Changes in the Proportions of the Human Body During the Period of Growth, J. Authropol. Inst. of Great Britain and Ireland 25, 1896.

13. Bohr, C.: Die funktionellen Aenderungen in der Mittellage und Vital Kapazität der Lungen, Deutsch. Arch. f. klin. Med. 88, 1906.

13 a. Hasselbach, K. A.: Ueber die Einwinkung der Temperatur auf die vitale Mittelage der Lungen. Ueber die Total Kapazität der Lungen, Deutsch. Arch. f. klin. med. 93, 1908.

14. Rubow, V.: Untersuchungen über die Atmung bei Herzkrankheiten; ein Beitrag zum Studium der Pathologie des kleinen Kreuslaufes, Deutsch. Arch. f. Klin. Med. 92, 1908.

15. Siebeck, R.: Ueber die Beinflussung der Atemmechanik durch krankhafte Zustande des Respirations und Kreislaufapparates, Deutsch. Arch. f. klin. Med. 100, 1910.

16. Bie, W., and Marr, W.: Dem Fall von angeborenem Herzfehler mit Cyanose und Polyglobulie, Deutsch. Arch. f. klin. Med. 99, 1910.

17. Plesch, J.: Die pathologische Physiologie des Lungen volumens und seine Beziehung zum Kreislauf, Ztschr. f. Exper. Path. u. Therap. 13: 1913.

18. Peabody, F. W., and Wentworth, J. A.: Clinical Studies on Respiration, IV. The Vital Capacity of the Lungs and Its Relation to Dyspnea, Arch. Int. Med. 20:468 (Sept.) 1917. Peabody, F. W.: Cardiac Dyspnea, Am. J. M. Sc. $155: 100,1918$.

19. Lundsgaard, C, and Van Slyke, D. D.: Studies of Lung Volume 1. Relation Between Thorax Size and Lung Volume in Normal Adults, J. Exper. M. 27:651, 1918. 
The chest they considered as a geometrical figure and the product of three dimensions was considered to represent a volume proportional to the chest volume. The height of the chest was taken as the length of the sternum from the superior border to a point just below the articulation with the xiphoid cartilage. The depth was taken as the horizontal distance from the middle of the sternum at the level of the insertion of the third costal cartilage, to the spinal column; and the breadth as the distance across the sixth rib in the mid axillary line.

The normal vital capacity in man and its relation to the size of the body has also been the subject of a paper published recently by Dreyer. ${ }^{20}$ Based largely on the data of Hutchinson ${ }^{6}$ and Schuster, ${ }^{21}$ together with some observations of his own, Dreyer has claimed that the vital capacity is a function of the weight. This, he says, can be expressed by the formula $\frac{\mathrm{W}^{\mathrm{a}}}{\mathrm{v} . \mathrm{c}}=\mathrm{K}$, where $\mathrm{W}$ is the net weight in grams, v.c. the vital capacity in cubic centimeters, the power $\mathrm{n}$ is 0.72 , and $\mathrm{K}$ is a constant. He further states that since it is already established that $\frac{\mathrm{W}^{\mathrm{a}}}{\mathrm{S}}=\mathrm{K}_{2}$ where $\mathrm{W}=$ net weight, $\mathrm{S}=$ body surface and $\mathrm{n}$ is 0.72 , it follows that the vital capacity is a simple function of the body surface.

The relation between the vital capacity and stem length Dreyer finds to be correctly expressed by the formula $\frac{\mathrm{SH}^{2}}{\mathrm{v} . \mathrm{c} .}=\mathrm{K}_{3}$ where $\mathrm{SH}=$ the stem length in centimeters, v.c. $=$ vital capacity in cubic centimeters, the power $\mathrm{n}$ is approximately 2 , and $\mathrm{K}_{3}$ is a constant. Between the vital capacity and the chest circumference the existing relation can be expressed by the formula $\frac{\mathrm{Ch}^{\mathrm{n}}}{\mathrm{v}, \mathrm{c} .}=\mathrm{K}_{4}$, where $\mathrm{Ch}=$ circumference of chest in cubic centimeters, v.c. $=$ the vital capacity in centimeters, the power $\mathrm{n}$ is approximately 2 , and $\mathrm{K}_{4}$ is a constant.

Also $\frac{\mathrm{SH} \times \mathrm{Ch}}{\mathrm{y}, \mathrm{c}}=\mathrm{K}_{5}$ where $\mathrm{SH}$ stem length in centimeters $\mathrm{Ch}=$ chest circumference in centimeters v.c. $=$ vital capacity in cubic centimeters, and $\mathrm{K}_{5}$ is a constant. Dreyer has pointed out, therefore, that the vital capacity is definitely related to the 0.72 power of the weight, directly to the body surface area, to the square of the stem length, to the square of the chest circumference, and to the trunk volume (estimated as the product of the chest circumference and stem length), and states that the above is also the order of the importance of these relations.

In discussing the variability of vital capacity in normal persons, Dreyer shows that for the 16 individuals which he studied the mean deviation, as estimated by the method of least squares, of the values

20. Dreyer, G.: Investigations on the Normal Vital Capacity in Man and its Relation to the Size of the Body, Lancet 2:227, 1919. Dreyer, G., and Burrell, L. S. T.: The Vital Capacity Constants Applied to the Study of Pulmonary Tuberculosis, Lancet 1:1212, 1920.

21. Schuster, E.: First results from the Oxford Authropometric Laboratory, Biometrika 8, 1911. 
for $\mathrm{K}$ computed from the formula based on the two thirds and the 0.72 power of the body weight, in the two cases amounted to 3.56 and 2.64 per cent., respectively, or distinctly lower when the best power for the weight $(0.72)$ is used. This, Dreyer says, indicates that if a person is found to have a vital capacity 6 per cent. smaller or larger than that calculated from his body surface, he probably has a normal vital capacity, and if the vital capacity is 10 per cent. above or below the normal it is almost certain to be abnormal. On using the data of Fitzgeralct. Purefoy and Haldane, ${ }^{22}$ however, a mean deviation of 15.8 per cent. is obtained, or five times as great as in Dreyer's series. Dreyer attributes this great difference in variability to the fact that the observations of Fitzgerald, Purefoy and Haldane were carried out on a more highly mixed material. He also calls attention to the differences in vital capacity exhibited by the different classes studied by Hutchinson, which apparently have nothing to do with fundamental bodily deficiencies but are simply a result of conditions depending upon occupation and mode of life.

The existence of normal individual difference of vital capacity has constituted a real difficulty in its practical clinical application, but aside from this study of Dreyer's, apparently no one has attempted to estimate its extent by statistical methods. It is absolutely essential to determine the magnitude of the deviation from the average met with in normal and healthy individuals, before it is possible to decide whether the vital capacity for any given person should be considered normal or abnormal. Knowing the extent of normal variability of vital capacity also enables one to more fully appreciate both the limitations and the possibilities of its applicability in clinical work. In this study an attempt is made to determine the extent of variability of vital capacity during childhood.

Before entering into a consideration of the normal variability, a consideration of the reliability of the averages obtained for the vital capacity seems appropriate. The measure of the trustworthiness of an average derived from a limited number of observations is furnished by the so-called probable error of randum sampling. To be more explicit, the probable error of random sampling is a measure of the extent that the average values would be expected to vary, were the observations made at random upon an infinitely large number of comparable series of cases, and is so chosen, that half of these values would lie inside, and half outside the limits of the probable error. Therefore in an infinitely large series roughly 50 per cent. of the averages will fall within the limit of the range of the probable error about the average based upon a limited number of cases. The probable error assumes

22. Fitzgerald, Purefoy, M., and Haldane, J. S.: The Normal Alveolar Carbonic Acid Pressure in Man, J. Physiol. 32, 1905. 
the data to be technically correct, and has nothing to do with inaccuracies in measurement. The probable error of the average or mean vital capacity at each age has been calculated by means of the formula $0.6745 \times \frac{\mathrm{S}}{\sqrt{\mathrm{n}}}$ where $\mathrm{S}=$ standard deviation, and $\mathrm{n}=$ number of observations, and the results obtained may be found in Tables 1 and 2 . The derivation and significance of the standard deviation is discussed at a later time.

During childhood it appears that in general, for the various groups, the calculated probable error of random sampling for each sex (Tables 1 and 2) constantly increases with advancing age. For the boys the value 15.6 c.c. at 6 years has increased to 29.8 c.c. at 15 years of age. With the girls during this same period the probable error increases from 14 at 6 to 24.3 at 15 years. In applying this information we can conclude for the boys at 15 years of age, that were the vital capacity taken for a large series of comparable groups of individuals the chances are that half these series would show averages falling between 3,145 c.c. \pm 29.8 c.c., while the remaining 50 per cent. lie either above or below this limit. In other words, for boys at this age, 50 per cent. of all group averages can be expected to vary not more than 29.8 c.c. above or 29.8 c.c. below that obtained. Derivations markedly beyond these limits probably indicate the existence of biological differences between the groups concerned.

The most commonly used measure of the dispersal of the individual measurements from the average of the sum of all the observations is the standard deviation. The standard deviation is obtained first by squaring all the deviations from the average, summing these squares, and then dividing this sum by the number of deviants, which gives the meansquare deviation. The square root of this mean-square deviation is designated as the standard deviation. The practical value of the standard deviation lies in the fact that it indicates the degree of the absolute variability, within the limits of which the probability is that the measurement obtained is more apt to be normal, and commonly the greater the deviation beyond the limits established by the standard deviation the greater the probability is that the measurement is abnormal. It is also particularly useful in the determination of measures of interrelationship.

The standard deviation from the average vital capacity of the lungs at each age has been calculated for the boys between 6 to 16 years, inclusive, and from 6 to 15 years for the girls (Tables 1 and 2). The number of subjects in each group during this period was considered sufficiently large to justify the procedure. Between 6 and 16 years of age for both sexes the absolute value of the standard deviation increases roughly three fold. With the boys it increases from about 182 c.c. at 
6 years to 573 c.c. at 16 years. If we attempt to apply this information in considering whether or not any single observation falls within normal limits, then at 16 years of age the vital capacity in individual cases might vary 573 c.c. either above or below the average value of 3,425 c.c. at this age, and could not be considered as definitely abnormal. In clinical work, however, those subjects approaching the lower limits of normal variability would, no doubt, cause the greater concern.

With the girls the standard deviation (Table 2) increases from 163 c.c. at 6 years to 413 c.c. at 15 years. At corresponding ages the absolute value of the standard deviations are usually somewhat smaller for the girls than for the boys.

In order to make comparison between the relative degree of variability of the vital capacity at different ages, it is necessary to reduce the various standard deviations to a comparable basis. This is readily accomplished by computing the percentage that the standard deviation at each age forms of the average vital capacity for that period. This relative variability constant is known as the coefficient of variation, and is in reality the per cent. that the standard deviation forms of the respective mean or average.

For the boys the coefficient of variation (Table 1) between 6 and 11 years of age apparently decreases from 15.8 to 13.6 . Thus at 6 years the normal variability of vital capacity expected is approximately 15.8 per cent. above or below the average for that age, which at 11 years has decreased to 13.6 per cent. During the following years the vital capacity becomes considerably more variable, the coefficient of variation at 14 years rising to 17.8 , with apparently a tendency to decrease during the succeeding two years.

For the girls the coefficient of variation (Table 2) decreases from 15 at 6 years to 13.5 at 8 years. Subsequently it rises, reaching a maximum of 17.5 at 13 years, one year earlier than the maximum coefficient of variation recorded for the boys. Later the variability apparently decreases. At 11 years of age an unusually low coefficient of 13.4 was obtained from the data, which possibly may be accidental in character. On consideration of the extent of variability in vital capacity it appears that for each sex variability decreases during early childhood, increases about the period of puberty, and later declines. In the main essentials the general trend of the variability in vital capacity is quite similar to that noted in respect to variability in weight and height during growth, for similarly the variability of these two physical measurements decreases at first, rises to attain a maximum about the time of puberty, and then diminishes again.

Although the standard deviation and the coefficient of variation gives a rough measure of the degree of absolute variability, a further conception of variability may be gained through the determination of the 
probable error of the data. Provided the curve of distribution of the individual observations conforms to the ideal mathematical type of symmetrical distribution curve, the statistical constant known as the probable error of the data establishes limits within which approximately 50 per cent. of all observations taken at random will be expected to fall. Of the remaining 50 per cent. of observations, 25 per cent. will lie above and 25 per cent. below the limits established. The probable error of the data may be computed by means of the formula $0.6745 \times \mathrm{SD}$, where SD is the standard deviation. In general, if a large number of observations is collected, one finds that the majority occur near the average value for the measurement taken, and the greater the deviation from the average the smaller the groups become. The frequency or distribution curve plotted for extensive series of observations often is found to conform very closely to the ideal symmetrical mathematical type of distribution or probability curve. Under such circumstances the determination of the probable error of the data of this series of observations is of especial significance as explained above. With respect to the observations on the vital capacity of the lungs the value and significance of the distribution curves based upon this data is greatly limited due to the small number of observations available. The data at present are insufficient to establish definitely the character of their distribution curve. At some later time it is hoped to be able to accumulate enough data to definitely establish an approximate limiting distribution curve for this measurement. To date, however, the curves obtained for the vital capacity in general appear to conform fairly well with the ideal symmetrical mathematical distribution curve. For the present, therefore, I feel it safe to assume that approximately 50 per cent. of cases taken at random will have vital capacities falling within the limits established by the probable error of the standard deviation for the group concerned. Twenty-five per cent. will lie above and 25 per cent. below these limits. If expressed in terms of per cent., the children constituting the last group, in general, have vital capacities 10 per cent. or more below the expected normal. By recording any individual vital capacity, one thus may easily classify the patient as to the group to which the child belongs. Subjects falling into the group representing the poorer one fourth of the child population are children who probably deserve special study to eliminate pulmonary or cardiac disease as a factor causing their low standard of physical fitness. Experience has shown, however, that an apparently normal vital capacity does not exclude the necessity of thorough examination when the patient is suspected of having tuberculosis, for occasionally the vital capacity may be normal as compared with averages, even in the presence of serious disease of the lungs. Should the accumulation of more extensive observation on the vital capacity of the lungs reveal the fact 
that the frequency curve derived from such data does not conform to the ideal symmetrical mathematical probability curve, but shows a certain definite skewness the above statements necessarily must be modified.

3. Vital Capacity and Standing Height.-In Tables 3 and 4 the data have been averaged in groups (sexes separated), each group including subjects differing $5 \mathrm{~cm}$. or less in standing height, age and other physical measurement being disregarded. With a growth from an average of $108 \mathrm{~cm}$. to $168 \mathrm{~cm}$. in height, the vital capacity for the boys (Table 4 ) has increased from 1,074 c.c. to 3,625 c.c., an increase of 2,551 c.c. Thus, with an increase of $60 \mathrm{~cm}$. in standing height representing approximately 54.5 per cent. growth of this measurement, the vital capacity has increased more than 237 per cent. On the whole, then, growth of vital capacity at this period with the boys, occurs about four times as rapidly as the growth in height.

For the girls, accompanying a growth in height from $108 \mathrm{~cm}$. to $168 \mathrm{~cm}$. the vital capacity (Table 4) increases from 1,022 c.c. to 3,017 c.c. This increase of 1,995 c.c. represents a percentage increase of about 195 per cent., as compared with 237 per cent. with the boys for a corresponding growth in height. Nevertheless, also with the girls the lung capacity increases more rapidly than increase in height occurs.

The increase in lung capacity for each sex as plotted against standing height is represented graphically by means of smoothed curves (as determined by graphic interpolation) in Figure 2. The curves for each sex when determined by this method tend to pursue a sinuous course, being somewhat concave in form with the boys up until the standing height reaches approximately $175 \mathrm{~cm}$., and with the girls until they become about $165 \mathrm{~cm}$. tall. Beyond these points the direction of each curve changes tending to straighten out to some extent. The greater vital capacity for the boys as compared with the girls of corresponding height is clearly shown. The extent of the difference between the boys and girls in general. appears to increase constantly as they grow taller. If we analyze the curves more completely we find that with the boys the increase in vital capacity plotted against height, is fairly uniform until the individuals are about $148 \mathrm{~cm}$. tall. With growth from $148 \mathrm{~cm}$. to $173 \mathrm{~cm}$. in height, the increase in vital capacity becomes more rapid, but beyond $173 \mathrm{~cm}$. it diminishes considerably in rate.

For the girls the most rapid increase in vital capacity accompanies the growth in height from 143 to $160 \mathrm{~cm}$.

The absolute increase in vital capacity (Tables.3 and 4) which accompanies each successive growth of $5 \mathrm{~cm}$. in standing height is fairly uniform with the boys until they become approximately $143 \mathrm{~cm}$. tall, and with the girls until they reach a standing height of $138 \mathrm{~cm}$. At 
table 3.-Normal Boys. Number of Cases, Average Standing Height, Average Vital Capacity, Mean Vital Capacity as Determined by Graphic Interpolation, Absolute and Percentage Increase in Vital. Capacity Accompanying Each 5 Car. Growth in Height, Vital Capacity as Computfo from Hetght by Formula for Each Height Group, Probable Error, Standard Deviation, and Coefficient of Variation

\begin{tabular}{|c|c|c|c|c|c|c|c|c|c|c|}
\hline $\begin{array}{l}\text { Number } \\
\text { of } \\
\text { Cases }\end{array}$ & $\begin{array}{l}\text { Standing } \\
\text { Height, } \\
\text { Cm. }\end{array}$ & $\begin{array}{l}\text { Average } \\
\text { Vital } \\
\text { Capaeity, } \\
\text { C.c. }\end{array}$ & $\begin{array}{c}\text { Mean V. C. } \\
\text { Determined } \\
\text { by Graphic } \\
\text { Interpolation, } \\
\text { C.c. } \\
\end{array}$ & $\begin{array}{c}\text { Absolute } \\
\text { Increase } \\
\text { in Vital } \\
\text { Capaeity, } \\
\text { C.e. }\end{array}$ & $\begin{array}{l}\text { Percentage } \\
\text { Inerease } \\
\text { in Vital } \\
\text { Oapacity, } \\
\text { C.e. }\end{array}$ & $\begin{array}{c}\text { Vital } \\
\text { Capaeity as } \\
\text { Computed } \\
\text { by Formula } \\
y=(\mathrm{ax}) \pm \mathrm{b}\end{array}$ & $\begin{array}{c}\text { Empirical Formula } \\
\text { for Each Height Group } \\
y=(a x) \pm b\end{array}$ & $\begin{array}{l}\text { Probable } \\
\text { Error of } \\
\text { Random } \\
\text { Sampling, } \\
\text { C.e. }\end{array}$ & $\begin{array}{l}\text { Standard } \\
\text { Deviation, } \\
\text { O.c. }\end{array}$ & $\begin{array}{l}\text { Coefficient } \\
\text { of Varia- } \\
\text { tion, } \\
\text { per } \\
\text { Cent. }\end{array}$ \\
\hline $\begin{array}{l}3 \\
6 \\
40 \\
83 \\
84\end{array}$ & $\begin{array}{r}98 \\
103 \\
108 \\
113 \\
118\end{array}$ & $\begin{array}{r}837 \\
788 \\
1,074 \\
1,190 \\
1,332\end{array}$ & $\begin{array}{r}837 \\
912 \\
1,062 \\
1,194 \\
1,340\end{array}$ & $\begin{array}{l}\dddot{75} \\
150 \\
132 \\
146\end{array}$ & $\begin{array}{l}\dddot{9.0} \\
16.4 \\
12.4 \\
12.2\end{array}$ & $\begin{array}{r}838 \\
963 \\
1,089 \\
1,214 \\
1,340\end{array}$ & $\begin{array}{l}\mathrm{y}=\mathrm{V} \cdot \mathrm{C} . \\
\mathrm{a}=\text { Height in } \mathrm{Cm} . \\
\mathrm{x}=25.1 \\
\mathrm{~b}=-1,622\end{array}$ & \multirow{4}{*}{$\begin{array}{l}15.0 \\
11.0 \\
11.1 \\
12.6 \\
13.6 \\
12.2 \\
14.0 \\
15.5 \\
15.8 \\
18.1 \\
22.4 \\
29.1 \\
31.7\end{array}$} & \multirow{2}{*}{$\begin{array}{l}140 \\
149 \\
151 \\
176 \\
197 \\
188 \\
227 \\
255 \\
278\end{array}$} & \multirow{2}{*}{$\begin{array}{l}13.0 \\
12.5 \\
11.8 \\
11.9 \\
11.7 \\
10.3 \\
11.1 \\
11.4 \\
11.8\end{array}$} \\
\hline $\begin{array}{r}89 \\
96 \\
109 \\
118 \\
123 \\
114\end{array}$ & $\begin{array}{l}123 \\
128 \\
133 \\
138 \\
143 \\
148\end{array}$ & $\begin{array}{l}1,474 \\
1,690 \\
1,628 \\
2,050 \\
2,230 \\
2,359\end{array}$ & $\begin{array}{l}1,500 \\
1,674 \\
1,853 \\
2,034 \\
2,220 \\
2,423\end{array}$ & $\begin{array}{l}160 \\
174 \\
179 \\
181 \\
186 \\
203\end{array}$ & $\begin{array}{r}11.9 \\
11.6 \\
10.7 \\
9.8 \\
9.1 \\
9.1\end{array}$ & $\begin{array}{l}1,499 \\
1,684 \\
1,869 \\
2,054 \\
2,239 \\
2,424\end{array}$ & $\begin{array}{l}y=V \cdot C . \\
\mathrm{a} \equiv \text { Height in } \mathrm{Cm} . \\
\mathrm{x}=37 \\
\mathrm{~b}=-3,052\end{array}$ & & & \\
\hline $\begin{array}{r}97 \\
115 \\
75 \\
77 \\
35\end{array}$ & $\begin{array}{l}153 \\
158 \\
163 \\
168 \\
173\end{array}$ & $\begin{array}{l}2,594 \\
2,936 \\
3,173 \\
3,625 \\
3,919\end{array}$ & $\begin{array}{l}2,660 \\
2,935 \\
3,243 \\
3,547 \\
3,815\end{array}$ & $\begin{array}{l}237 \\
255 \\
308 \\
304 \\
268\end{array}$ & $\begin{array}{r}9.8 \\
9.5 \\
10.5 \\
9.4 \\
7.6\end{array}$ & $\begin{array}{l}2,659 \\
2,948 \\
3,237 \\
3,526 \\
3,815\end{array}$ & $\begin{array}{l}\mathrm{y}=\mathrm{V} . \mathrm{C} . \\
\mathrm{a} \equiv \text { Height in } \mathrm{Cm} . \\
\mathrm{x}=57.8 \\
\mathrm{~b}=-6.18 \mathrm{1}\end{array}$ & & $\begin{array}{l}264 \\
357 \\
373 \\
413\end{array}$ & $\begin{array}{l}10.2 \\
12.2 \\
11.7 \\
11.5\end{array}$ \\
\hline $\begin{array}{r}16 \\
3 \\
1\end{array}$ & $\begin{array}{l}178 \\
183 \\
188\end{array}$ & $\begin{array}{l}4,094 \\
4,167 \\
4,300\end{array}$ & $\begin{array}{l}4,020 \\
4,175 \\
4,300\end{array}$ & $\begin{array}{l}205 \\
155 \\
125\end{array}$ & $\begin{array}{l}5.4 \\
3.9 \\
3.0\end{array}$ & $\begin{array}{l}4,020 \\
4,160 \\
4,300\end{array}$ & $\begin{array}{l}y=v . C . \\
\mathrm{a}=\text { Height in } \mathrm{Cm} . \\
\mathrm{x}=28 \quad \mathrm{~b}=-964\end{array}$ & & & \\
\hline
\end{tabular}


Table 4.-Normal Girls. Number of Cases, Average Standing Height, Average Vital Capactiy, Mean Vital Capacity as Determined by Graphic Interpolation, Absolute and Percentage Increase in Vital Capacity Accompanying Each 5 Cm. Growth in Height, Vital Capacity as Computed from Height by Formula, formula for Each Height Group, Probable Error, Standard Deviation, and Coefficient of Variation

\begin{tabular}{|c|c|c|c|c|c|c|c|c|c|c|}
\hline $\begin{array}{c}\text { Number } \\
\text { of } \\
\text { Cases }\end{array}$ & $\begin{array}{c}\text { Standing } \\
\text { Height, } \\
\text { Cm. }\end{array}$ & $\begin{array}{c}\text { Average } \\
\text { Vital } \\
\text { Capacity, } \\
\text { C.c. }\end{array}$ & $\begin{array}{l}\text { Mean V. C. } \\
\text { Determined } \\
\text { by Graphic } \\
\text { Interpola- } \\
\text { tion, } \\
\text { O.c. }\end{array}$ & $\begin{array}{l}\text { Absolute } \\
\text { Increase } \\
\text { in } \\
\text { Vital } \\
\text { Capacity. } \\
\text { C.c. }\end{array}$ & $\begin{array}{l}\text { Percentage } \\
\text { Inerease in } \\
\text { vital Capacity } \\
\text { with } 5 \mathrm{Cm} \text {. } \\
\text { Growth in } \\
\text { Length, C.c. }\end{array}$ & $\begin{array}{c}\text { Vital } \\
\text { Capacity as } \\
\text { Computed } \\
\text { by Formula } \\
y=(a x) \pm b\end{array}$ & $\begin{array}{c}\text { Empirieal Formula } \\
\text { for Each Height Group } \\
y=(a x) \pm b\end{array}$ & $\begin{array}{l}\text { Probable } \\
\text { Error of } \\
\text { Random } \\
\text { Sampling. } \\
\text { C.c. }\end{array}$ & $\begin{array}{c}\text { Stnndard } \\
\text { Deviation, } \\
\text { C.e. }\end{array}$ & $\begin{array}{l}\text { Coefficient } \\
\text { of Varia- } \\
\text { tion, } \\
\text { per } \\
\text { Cent. }\end{array}$ \\
\hline $\begin{array}{r}5 \\
20 \\
37 \\
68\end{array}$ & $\begin{array}{r}98 \\
103 \\
108 \\
113\end{array}$ & $\begin{array}{r}755 \\
851 \\
1,022 \\
1,118\end{array}$ & $\begin{array}{r}755 \\
876 \\
1,005 \\
1,136\end{array}$ & $\begin{array}{l}121 \\
129 \\
131\end{array}$ & $\begin{array}{l}10.0 \\
14.7 \\
13.0\end{array}$ & $\begin{array}{r}755 \\
882 \\
1,010 \\
1,137\end{array}$ & $(25.5 \times$ Ht. $)-1,74=$ & \multirow{4}{*}{$\begin{array}{l}11.9 \\
12.2 \\
10.6 \\
12.7 \\
12.9 \\
13.4 \\
14.8 \\
17.3 \\
16.4 \\
18.6 \\
22.8\end{array}$} & \multirow{4}{*}{$\begin{array}{l}146 \\
153 \\
146 \\
173 \\
185 \\
203 \\
\\
229 \\
254 \\
312 \\
328 \\
332\end{array}$} & \multirow{4}{*}{$\begin{array}{l}13.1 \\
11.9 \\
10.3 \\
11.1 \\
10.9 \\
10.9 \\
\\
11.4 \\
11.5 \\
12.7 \\
12.3 \\
11.6\end{array}$} \\
\hline $\begin{array}{r}71 \\
86 \\
85 \\
93 \\
104\end{array}$ & $\begin{array}{l}118 \\
123 \\
128 \\
133 \\
138\end{array}$ & $\begin{array}{l}1,283 \\
1,412 \\
1,555 \\
1,698 \\
1,870\end{array}$ & $\begin{array}{l}1,276 \\
1,414 \\
1,560 \\
1,707 \\
1,865\end{array}$ & $\begin{array}{l}140 \\
138 \\
146 \\
147 \\
158\end{array}$ & $\begin{array}{r}12.3 \\
108 \\
10.3 \\
9.4 \\
9.3\end{array}$ & $\begin{array}{l}1,276 \\
1,423 \\
1,571 \\
1,718 \\
1.866\end{array}$ & $(29.5 \times$ Ht. $)-2,205=$ & & & \\
\hline $\begin{array}{r}109 \\
98 \\
164 \\
141 \\
96\end{array}$ & $\begin{array}{l}143 \\
148 \\
153 \\
158 \\
163\end{array}$ & $\begin{array}{l}2,005 \\
2,211 \\
2,449 \\
2,661 \\
2,855\end{array}$ & $\begin{array}{l}2,036 \\
2,230 \\
2,439 \\
2,646 \\
2,830\end{array}$ & $\begin{array}{l}171 \\
194 \\
209 \\
207 \\
184\end{array}$ & $\begin{array}{l}9.2 \\
9.5 \\
9.4 \\
8.5 \\
7.0\end{array}$ & $\begin{array}{l}2,036 \\
2,234 \\
2,432 \\
2,631 \\
2,830\end{array}$ & $(39.7 \times \underset{\text { Vt. })}{\text { v. C. }}-3,641=$ & & & \\
\hline $\begin{array}{r}35 \\
3\end{array}$ & $\begin{array}{l}168 \\
173\end{array}$ & $\begin{array}{l}3,017 \\
3,100\end{array}$ & $\begin{array}{l}2,978 \\
3,100\end{array}$ & $\begin{array}{l}148 \\
122\end{array}$ & $\begin{array}{l}5.2 \\
4.1\end{array}$ & $\begin{array}{l}2.978 \\
3.100\end{array}$ & $(24.3 \times$ Ht. $)-1,104=$ & & & \\
\hline
\end{tabular}


these points the absolute increase rises rapidly reaching a maximum of 308 c.c. for the boys when $163 \mathrm{~cm}$. tall, as compared with 209 c.c. for the girls at a standing height of $153 \mathrm{~cm}$. Subsequently the absolute increase for each sex steadily declines. Evidently, therefore, with each sex the increase in vital capacity for each $5 \mathrm{~cm}$. growth in height is not uniform throughout childhood. Hutchinson's conclusion, based on data collected largely from adults, that vital capacity increases in a simple arithmetical progression with increasing height certainly does not apply to the period of childhood. Dreyer has demonstrated recently from Hutchinson's data that this contention was erroneous, and has shown that even for adults the vital capacity is not a simple function of the body height, since it increases in an irregular manner and not at a fixed rate with each unit increase in height.

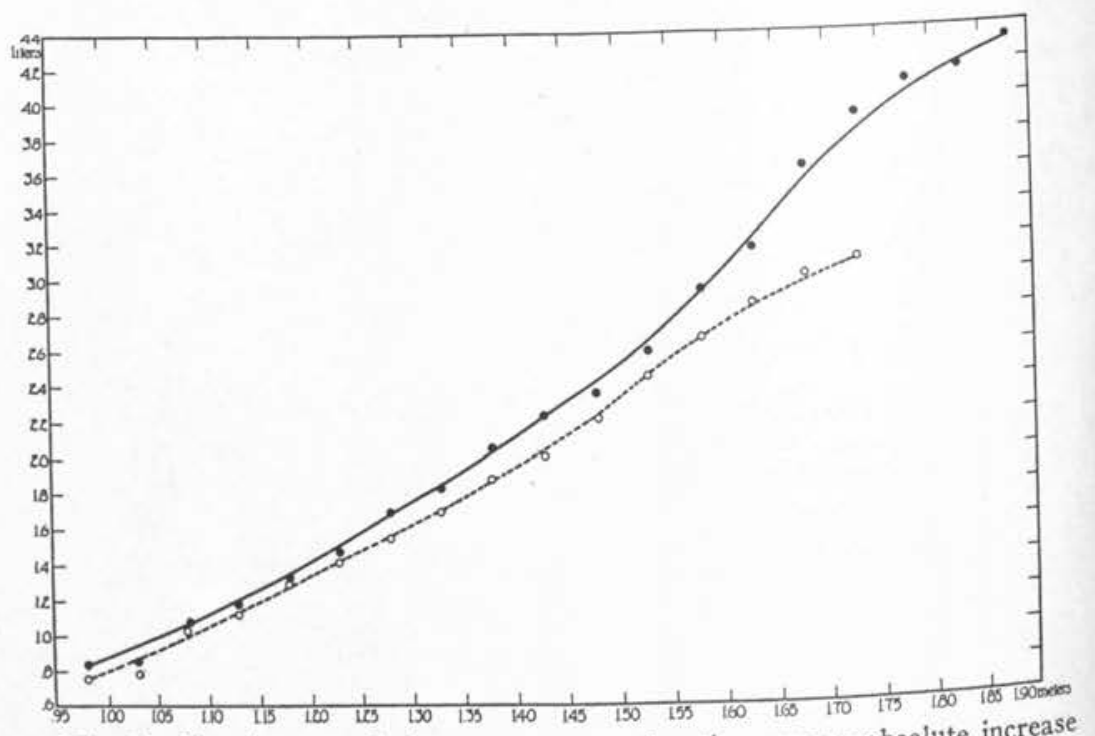

Fig. 2.-Showing smoothed curves representing the average absolute increase in the vital capacity of the lungs as determined by graphic interpolation, for boys between 0.98 and 1.88 meters tall inclusive, and for girls between and 1.73 meters tall inclusive. The actual observed averages at each standing height are represented by dots for boys, and by circles for the girls. meters capacity in liters is represented on the ordinate, and standing height in meters on the abscissa.

The relative increase in vital capacity accompanying each $5 \mathrm{~cm}$. growth in standing height (Tables 3 and 4 ) apparently diminishes throughout childhood. There is a slight indication of an increase in percentage growth in vital capacity for the boys between 153 and 168 $\mathrm{cm}$. standing height, and for the girls from 148 to $153 \mathrm{~cm}$. tall. The slight tendency to acceleration in rate after an earlier period of decline is much less striking in the case of the averages based on standing height, as compared with that based on age. 
As in the case of the curves for vital capacity as plotted against age, likewise those plotted against standing height may be divided into several phases so selected that each phase conforms very closely to a straight line. The empirical formula $\mathrm{y}=(a x) \pm b$ by which each of these straight lines may be derived, therefore, affords a fairly satisfactory method by which the vital capacity at any height may be computed when $\mathrm{y}=$ the vital capacity, $a=$ the standing height in $\mathrm{cm}$., $\mathrm{x}=\mathrm{a}$ constant, and $\pm b=\mathrm{a}$ second constant. The vital capacities, as computed by means of the above formula, are recorded in Tables 3 and 4 , and, in general, agree fairly closely with the averages as determined by means of graphic interpolation. The constants used in computing the values for each portion of the two curves may be obtained by referring to Tables 3 and 4 .

The probable error of random sampling (Tables 3 and 4) computed for the vital capacities as averaged according to standing height, in general, with each sex tends to become larger as the individuals grow taller and have a greater lung capacity. For all groups, however, the probable error is comparatively small.

The standard deviations about the means based on standing height (Tables 3 and 4) for each sex tend to increase as the groups become taller, and are, as a rule, greater for the boys than for the girls of corresponding height. In general, the absolute values obtained for the standard deviation seem to be somewhat greater when the data are averaged in groups differing one year in age, as compared with the deviation occurring when the subjects are averaged in groups differing $5 \mathrm{~cm}$. in standing height.

On reducing the standard deviation to the coefficient of variation (Tables 3 and 4 ) one finds the vital capacity from each sex to become relatively less variable with increasing height until they become $133 \mathrm{~cm}$. tall. Subsequently the variability increases 2 per cent. for a short period and later declines. The general trend of relative variability in vital capacity with relation to average based upon either age or height are quite similar, in both instances showing a tendency to decrease at first, followed by a period of increased variability, which later declines again. The actual values for the coefficients of variation (Tables 3 and 4 ), for the most part, vary between 10.5 and 12.5 . It appears, therefore, that individual records of vital capacity fluctuating between 12 per cent. above, or 12 per cent. below the average expected for corresponding height, could not be interpreted as definitely abnormal. Should the record vary more than 12 per cent. below the averages, the individual record immediately falls into the class that are apt to be abnormal, and such persons, no doubt, should be examined with care to determine the cause of their low standard of physicla fitness in this respect. 
If the coefficients of variation for the averages based on age are compared with those derived from averages based on height, the values will be found to be considerably higher in the former case. Due to the presence of less variability, it appears, therefore, that averages based on grouping of the subjects differing $5 \mathrm{~cm}$. in standing height, for more satisfactory normal standards, than the averages based on age at yearly intervals.

By distributing and averaging the cases at each age according to height, as accomplished in Tables 5 and 6 , one is able to gain some conception of the influence of these two factors on the vital capacity. When arranged in this manner it is plainly evident that at any age the taller subjects tend to have a much larger vital capacity than the shorter ones of the same age. This holds true for the girls as well as for the boys. The difference is quite considerable in many instances. Thus, for example, at 14 years of age the average vital capacity for twentyfive girls approximately $150 \mathrm{~cm}$. tall was 2,292 c.c., whereas for thirty-five girls of the same age but approximately $15 \mathrm{~cm}$. taller, the vital capacity averaged 2,824 c.c. or 532 more than for the shorter group. The condition of other ages is similar. It is evident, therefore, that at any age differences in standing height influence the vital capacity to a considerable degree. If we now consider the influence of age on the vital capacity for individuals of about the same standing height no such striking difference is found. In several instances the average vital capacity is slightly greater for the older than for the younger individuals of corresponding average height, but this is not consistently the case. On the whole, it seems clear that the difference in the vital capacity of the lungs among children of the same age but differing considerably in height, is far more striking than the differences noted among children of the same height but of different age. However, in comparing individual records with normal standards it is probably advisable to take both age and height into consideration.

4. Vital Capacity and Sitting Height.-In Tables 7 and 8 the data for each sex have been averaged in groups, each group including sub-
jects differing $2 \mathrm{~cm}$. or less in sitting height.

For the boys the averages (Table 7 ) indicate that with an increase in stem length from 57 to $87 \mathrm{~cm}$. the vital capacity increases from 1,071 to 3,607 c.c. Hence, with a growth of $30 \mathrm{~cm}$. in stem length, the vital capacity shows an average increase of 2,536 c.c., or nearly 237 per cent.

With the girls (Table 8 ) for a similar growth in sitting height, the vital capacity increases from an average of 908 c.c. at $57 \mathrm{~cm}$. stem length to 2,967 c.c. at $87 \mathrm{~cm}$. stem length. The percentage increase in this case amounts to 197 per cent, or approximately 40 per cent. less than the increase registered by the boys for a similar growth in 
table 5.-Vital Capacity, in Cubic Centimeters, of Normal Boys, for Each 5 Cm. Difference in Standing Height at Each Age, and Average Vital Capacity for Each 5 Cm. of Growth in Height, Combining all Ages

\begin{tabular}{|c|c|c|c|c|c|c|c|c|c|c|c|c|c|c|c|c|c|c|c|}
\hline \multirow{2}{*}{ Age in Years } & \multicolumn{19}{|c|}{ Standing Height } \\
\hline & 98 & 103 & 108 & 113 & 118 & 123 & 128 & 133 & 138 & 143 & 148 & 153 & 158 & 163 & 168 & 173 & 178 & 183 & 188 \\
\hline $\begin{array}{r} \\
5 \\
6 \\
7 \\
8 \\
9 \\
9 \\
10 \ldots \ldots \ldots \ldots \ldots\end{array}$ & 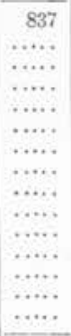 & 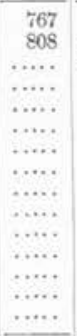 & $\begin{array}{r}978 \\
1,122 \\
1,079 \\
\ldots \ldots . \\
\ldots \ldots . \\
\ldots \ldots . \\
\ldots \ldots . \\
\ldots \ldots . \\
\ldots \ldots . \\
\ldots \ldots . \\
\ldots \ldots . \\
\ldots \ldots \\
\end{array}$ & $\begin{array}{r}975 \\
1,159 \\
1,215 \\
1,242 \\
1,400 \\
\ldots \ldots . \\
\ldots \ldots . \\
\ldots \ldots . \\
\ldots \ldots . \\
\ldots \ldots . \\
\ldots \ldots . \\
\ldots \ldots . \\
\end{array}$ & $\begin{array}{r}925 \\
1,245 \\
1,303 \\
1,355 \\
1,450 \\
1,525 \\
\ldots \ldots . \\
\ldots \ldots . \\
\ldots \ldots . \\
\ldots \ldots . \\
\ldots \ldots . \\
\ldots \ldots . \\
\ldots \ldots \\
\end{array}$ & $\begin{array}{l}1,333 \\
1,396 \\
1,480 \\
1,537 \\
1,660 \\
1,463 \\
1,300 \\
\ldots \ldots . \\
\ldots \ldots . \\
\ldots \ldots . \\
\ldots \ldots . \\
\ldots \ldots . \\
\ldots . .6\end{array}$ & $\begin{array}{l}\ldots \ldots . \\
\ldots \ldots \\
1,620 \\
1,707 \\
1,672 \\
1,662 \\
1,808 \\
1,575 \\
\ldots \ldots . \\
\ldots \ldots . \\
\ldots \ldots . \\
\ldots \ldots . \\
\ldots \ldots . \\
\end{array}$ & $\begin{array}{l}\ldots \ldots . \\
\ldots \ldots . \\
1,6.60 \\
1,794 \\
1,872 \\
1.827 \\
1.800 \\
1,908 \\
\ldots \ldots . \\
\ldots \ldots . \\
\ldots \ldots . \\
\ldots \ldots . \\
\end{array}$ & $\begin{array}{l}\ldots . . . \\
2.200 \\
1.800 \\
1992 \\
2.001 \\
2065 \\
2059 \\
2,132 \\
1938 \\
\ldots \ldots . \\
\ldots \ldots . \\
\ldots \ldots . \\
\ldots . . \\
\end{array}$ & $\begin{array}{l}\ldots . . \\
\ldots . . \\
\ldots \ldots . \\
2,075 \\
2,275 \\
2,2,150 \\
2,151 \\
2,244 \\
2,298 \\
2,445 \\
2,400 \\
\ldots \ldots . \\
\ldots . . \\
\ldots . .\end{array}$ & 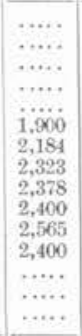 & $\begin{array}{l}\ldots . . \\
\ldots . . \\
\ldots \ldots . \\
\ldots \ldots . \\
\ldots \ldots . \\
\ldots \ldots . \\
2,6.5 \\
2,545 \\
2,584 \\
2,727 \\
2,400 \\
\ldots \ldots . \\
\ldots \ldots . \\
\ldots . . \\
\end{array}$ & $\begin{array}{c}\ldots . . \\
\ldots . . \\
\ldots . . \\
\ldots . . \\
\ldots \ldots . \\
\ldots \ldots . \\
\ldots . .6 \\
2,975 \\
2,768 \\
2,906 \\
2,971 \\
3,236 \\
2,833 \\
2,750 \\
\ldots . . \\
\end{array}$ & 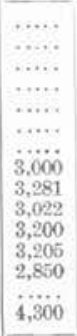 & $\begin{array}{c}\ldots . . . \\
\ldots \ldots . \\
\ldots \ldots . \\
\ldots \ldots . \\
\ldots \ldots . \\
\ldots \ldots . \\
\ldots \ldots . \\
3.400 \\
3,328 \\
3,673 \\
3.644 \\
3.813 \\
3,925 \\
4,300 \\
\end{array}$ & $\begin{array}{l}\ldots . . . \\
\ldots . . \\
\ldots . . \\
\ldots . . \\
\ldots . . \\
\ldots . . \\
\ldots . . \\
\ldots . . \\
3,538 \\
3,893 \\
3,958 \\
3.973 \\
4,125 \\
4,300 \\
\end{array}$ & $\begin{array}{c}\ldots \ldots . \\
\ldots \ldots . \\
\ldots \ldots . \\
\ldots \ldots . \\
\ldots \ldots . \\
\ldots \ldots . \\
\ldots \ldots . \\
\ldots \ldots . \\
3,900 \\
3,862 \\
4,180 \\
4,262 \\
4,200 \\
\ldots \ldots \\
\end{array}$ & 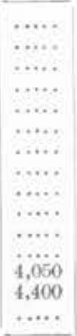 & $\begin{array}{c}\ldots . . \\
\ldots \ldots . \\
\ldots . . \\
\ldots \ldots . \\
\ldots \ldots . \\
\ldots \ldots . \\
\ldots \ldots . \\
\ldots \ldots . \\
\ldots \ldots . \\
4 \ldots . \\
4,300 \\
\ldots \ldots \\
\ldots . .\end{array}$ \\
\hline Absolute inereased vital capacity.... & 837 & 788 & 1,074 & 1,190 & 1,332 & 1,474 & 1,690 & 1,828 & 2,050 & 2,230 & 2,359 & 2,594 & 2,936 & 3,173 & 3,625 & 3,919 & 4,094 & 4,167 & 4,300 \\
\hline
\end{tabular}

TABle 6.-Vital. Capacity, in Cubic Centimeters, of Girls, for Each 5 Cm. Difference in Standing Height at Each Age, and Average Vital Capacity for Each 5 Cm. of Growth in Height. Combining All Ages

\begin{tabular}{|c|c|c|c|c|c|c|c|c|c|c|c|c|c|c|c|c|c|c|}
\hline \multirow{2}{*}{ Age in Years } & \multicolumn{18}{|c|}{ Stending Height } \\
\hline & 88 & 95 & 98 & 103 & 108 & 113 & 118 & 123 & 128 & 133 & 138 & 143 & 148 & 153 & 158 & 163 & 168 & 173 \\
\hline & 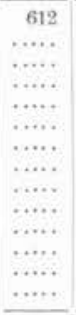 & 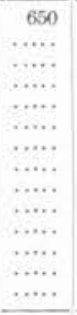 & $\begin{array}{l}692 \\
850 \\
\ldots \ldots . \\
\ldots \ldots . \\
\ldots \ldots . \\
\ldots \ldots . \\
\ldots \ldots . \\
\ldots \ldots . \\
\ldots \ldots . \\
\ldots \ldots . \\
\ldots \ldots \\
\end{array}$ & $\begin{array}{r}850 \\
850 \\
806 \\
950 \\
900 \\
\ldots \ldots . \\
\ldots \ldots . \\
\ldots \ldots . \\
\ldots \ldots . \\
\ldots \ldots . \\
\ldots \ldots . \\
\ldots \ldots \\
\end{array}$ & 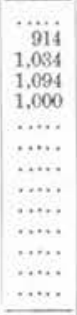 & $\begin{array}{l}1,050 \\
1,062 \\
1,131 \\
1,231 \\
1,150 \\
1,075 \\
\ldots \ldots . \\
\ldots \ldots . \\
\ldots \ldots . \\
\ldots \ldots . \\
\ldots \ldots \\
\end{array}$ & $\begin{array}{l}1.100 \\
1,283 \\
1,239 \\
1,311 \\
1,294 \\
1,333 \\
1,2325 \\
\ldots \ldots . \\
\ldots \ldots . \\
\ldots \ldots . \\
\ldots \ldots \\
\end{array}$ & $\begin{array}{l}\text {..... } \\
1.317 \\
1.356 \\
1.444 \\
1.430 \\
1,423 \\
1.342 \\
1,450 \\
\ldots \ldots . . \\
\ldots \ldots . . \\
\ldots \ldots . . \\
\end{array}$ & $\begin{array}{l}\ldots \ldots . \\
\cdots \ldots . . \\
1,440 \\
1.455 \\
1.509 \\
1,588 \\
1,632 \\
1,725 \\
1,650 \\
\cdots \cdots \\
\cdots \cdots \\
\cdots \cdots \\
\end{array}$ & $\begin{array}{l}\ldots . . \\
\ldots \ldots . \\
1,800 \\
1,780 \\
1,687 \\
1.684 \\
1,703 \\
1,700 \\
1,650 \\
\ldots \ldots . \\
\ldots \ldots . \\
\ldots \ldots . \\
\end{array}$ & $\begin{array}{l}\ldots . . \\
\ldots . . \\
\ldots \ldots . \\
\ldots \ldots . \\
1, .820 \\
1,821 \\
1,820 \\
1,925 \\
1,957 \\
2,150 \\
\ldots \ldots . \\
\ldots \ldots . \\
\ldots . .\end{array}$ & $\begin{array}{l}\ldots . . . \\
\ldots . . \\
\ldots \ldots . \\
\ldots \ldots . \\
1,850 \\
1,980 \\
1,943 \\
1,996 \\
2,020 \\
2,200 \\
2,210 \\
\ldots \ldots . \\
\ldots . . \\
\end{array}$ & $\begin{array}{c}\ldots . . . \\
\ldots \ldots . \\
\ldots \ldots . \\
\ldots \ldots . \\
\ldots \ldots . \\
2,183 \\
2,143 \\
2,110 \\
2,257 \\
2.292 \\
2,294 \\
\ldots \ldots . \\
\ldots \ldots\end{array}$ & $\begin{array}{l}\ldots . . \\
\ldots \ldots . \\
\ldots \ldots . \\
\ldots \ldots . \\
\ldots \ldots . \\
\ldots \ldots . \\
2,150 \\
2,050 \\
2,352 \\
2,381 \\
2,467 \\
2,590 \\
2,733 \\
2,250\end{array}$ & $\begin{array}{l}\ldots . . \\
\ldots \ldots . \\
\ldots \ldots . \\
\ldots \ldots . \\
\ldots \ldots . \\
\ldots \ldots . \\
\ldots \ldots . \\
2,533 \\
2,515 \\
2,678 \\
2,708 \\
2,786 \\
\ldots \ldots \\
\end{array}$ & $\begin{array}{l}\ldots . . \\
\ldots . . \\
\ldots \ldots . \\
\ldots \ldots . \\
\ldots \ldots . \\
\ldots . . \\
\ldots \ldots . \\
\ldots . . \\
2,950 \\
2,865 \\
2,824 \\
2,869 \\
2,733 \\
3,030\end{array}$ & $\begin{array}{c}\ldots . . \\
\ldots . . \\
\ldots . . \\
\ldots \ldots . \\
\ldots . . \\
\ldots \ldots . \\
\ldots \ldots . \\
\ldots \ldots . \\
30.6 \\
3040 \\
3,131 \\
3,010 \\
2,850 \\
3,100\end{array}$ & 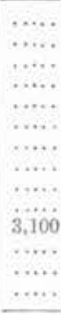 \\
\hline Average vital capacity ..................... & $\overline{612}$ & 650 & 755 & 851 & $\overline{1,022}$ & 1,118 & 1,238 & 1,412 & 1,555 & 1,698 & 1,870 & 2,005 & 2,211 & 2,449 & 2,661 & 2,855 & 3,017 & 3,100 \\
\hline
\end{tabular}


table 7.-Normal Boys. Number of Cases, Sitting Height, Average Vital Capacity, Vital Capacity as Determined by Graphic Interpolation Absolute and Percentage Increase in Vital. Capacity Accompanying Each 2 Cm. Growth in Stem

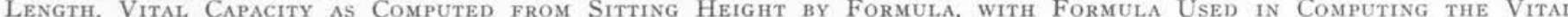
Capacity Corrected Sitting Height and Values Derived froy Formula Souare of Sitting Height in CM., Probable Error, Standard Deviation, and Coefficient of Variation

\begin{tabular}{|c|c|c|c|c|c|c|c|c|c|c|c|c|}
\hline $\begin{array}{l}\text { Number } \\
\text { of } \\
\text { Cases }\end{array}$ & $\begin{array}{l}\text { Sitting } \\
\text { Height, } \\
\text { Cm. }\end{array}$ & $\begin{array}{l}\text { Average } \\
\text { Vital } \\
\text { Capacity. } \\
\text { C.e. }\end{array}$ & $\begin{array}{c}\text { Mean Vital } \\
\text { Capaeity } \\
\text { as } \\
\text { Determined } \\
\text { by } \\
\text { Graphic } \\
\text { Interpo- } \\
\text { lation, } \\
\text { C.e. } \\
\end{array}$ & $\begin{array}{c}\text { Absolute } \\
\text { Inerease in } \\
\text { Vital Ca- } \\
\text { paeity with } \\
\text { Eaeh } 2 \text { Om. } \\
\text { Growth in } \\
\text { Standing } \\
\text { Height. } \\
\text { Om. } \\
\end{array}$ & $\begin{array}{c}\text { Percentage } \\
\text { Yearly } \\
\text { Inerease in } \\
\text { V. O. wlth } \\
\text { Each } 2 \mathrm{Cm} . \\
\text { Growth in } \\
\text { Standing } \\
\text { Height, } \\
\text { Cm. } \\
\end{array}$ & $\begin{array}{c}\text { Vital } \\
\text { Capacity } \\
\text { as } \\
\text { Computed } \\
\text { by } \\
\text { Formula } \\
y=(a x) \pm b\end{array}$ & $\begin{array}{l}\text { Formula Used for } \\
\text { Each Sitting Height } \\
\text { Group } \\
y=(\mathrm{ax}) \pm \mathrm{b}\end{array}$ & $\begin{array}{l}\text { Cor- } \\
\text { rected } \\
\text { Sitting } \\
\text { Height }\end{array}$ & $\frac{\mathrm{S} \cdot \mathrm{H} \cdot \mathrm{C}^{2}}{\mathrm{v} \cdot \mathrm{c} .}$ & $\begin{array}{c}\text { Probable } \\
\text { Error of } \\
\text { Random } \\
\text { Sampling, } \\
\text { C.e. }\end{array}$ & $\begin{array}{l}\text { Standard } \\
\text { Devia- } \\
\text { tion, } \\
\text { C.e. }\end{array}$ & $\begin{array}{l}\text { Coeffl- } \\
\text { elent of } \\
\text { Varia- } \\
\text { tion, } \\
\text { per Cent. }\end{array}$ \\
\hline $\begin{array}{r}2 \\
7 \\
27 \\
51 \\
75\end{array}$ & $\begin{array}{l}53 \\
55 \\
57 \\
59 \\
61\end{array}$ & $\begin{array}{r}975 \\
1,036 \\
1,071 \\
1,190 \\
1,302\end{array}$ & $\begin{array}{r}975 \\
1,034 \\
1,123 \\
1,214 \\
1,307\end{array}$ & $\begin{array}{l}59 \\
89 \\
91 \\
93\end{array}$ & $\begin{array}{l}\dddot{6} .1 \\
8.6 \\
8.1 \\
7.7\end{array}$ & $\begin{array}{r}975 \\
1,058 \\
1,141 \\
1,224 \\
1,307\end{array}$ & 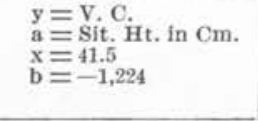 & $\begin{array}{l}51.4 \\
53.3 \\
55.3 \\
57.2 \\
59.2\end{array}$ & $\begin{array}{l}2.71 \\
2.75 \\
2.72 \\
2.70 \\
2.68\end{array}$ & $\begin{array}{l}\ldots \ldots \\
\dddot{3} .9 \\
11.3 \\
10.6\end{array}$ & $\begin{array}{l}\ldots \\
1351 \\
139 \\
187\end{array}$ & $\begin{array}{l}\ldots . . \\
11.1 \\
11.7 \\
14.4\end{array}$ \\
\hline $\begin{array}{r}78 \\
76 \\
84 \\
73 \\
78 \\
79 \\
113 \\
85\end{array}$ & $\begin{array}{l}63 \\
65 \\
67 \\
69 \\
71 \\
73 \\
75 \\
77\end{array}$ & $\begin{array}{l}1,425 \\
1,557 \\
1,719 \\
1,923 \\
2,054 \\
2,159 \\
2,300 \\
2,497\end{array}$ & $\begin{array}{l}1,434 \\
1,576 \\
1,733 \\
1,802 \\
2,038 \\
2,178 \\
2,326 \\
2,497\end{array}$ & $\begin{array}{l}127 \\
142 \\
157 \\
159 \\
146 \\
140 \\
148 \\
171\end{array}$ & $\begin{array}{r}9.7 \\
9.9 \\
10.0 \\
9.2 \\
7.7 \\
6.8 \\
6.8 \\
7.4\end{array}$ & $\begin{array}{l}1,434 \\
1,586 \\
1,738 \\
1,890 \\
2,042 \\
2,194 \\
2,346 \\
2,498\end{array}$ & $\begin{array}{l}\mathrm{y}=\mathrm{V} \cdot \mathrm{C} . \\
\mathrm{a} \equiv \mathrm{Sit} . \mathrm{Ht} \text {. in } \mathrm{Om} . \\
\mathrm{x} \equiv 76 \\
\mathrm{~b}=-3,354\end{array}$ & $\begin{array}{l}61.1 \\
63.1 \\
65.0 \\
68.9 \\
88.9 \\
70.8 \\
72.8 \\
74.7\end{array}$ & $\begin{array}{l}2.60 \\
2.53 \\
2.44 \\
2.42 \\
2.31 \\
2.30 \\
2.28 \\
2.23\end{array}$ & $\begin{array}{l}10.9 \\
12.1 \\
12.6 \\
15.2 \\
11.7 \\
16.4 \\
15.1 \\
18.5\end{array}$ & $\begin{array}{l}209 \\
221 \\
219 \\
217 \\
214 \\
258 \\
239 \\
276\end{array}$ & $\begin{array}{l}14.7 \\
14.2 \\
112.8 \\
11.3 \\
10.9 \\
12.0 \\
10.4 \\
11.1\end{array}$ \\
\hline $\begin{array}{l}60 \\
91 \\
64 \\
49 \\
47 \\
32\end{array}$ & $\begin{array}{l}79 \\
81 \\
83 \\
85 \\
87 \\
89\end{array}$ & $\begin{array}{l}2,671 \\
2,881 \\
3,104 \\
3,292 \\
3,607 \\
3,897\end{array}$ & $\begin{array}{l}2,686 \\
2,887 \\
3,104 \\
3,342 \\
3,580 \\
3,796\end{array}$ & $\begin{array}{l}189 \\
201 \\
217 \\
238 \\
238 \\
216\end{array}$ & $\begin{array}{l}7.6 \\
7.5 \\
7.5 \\
7.7 \\
7.1 \\
6.0\end{array}$ & $\begin{array}{l}2,686 \\
2,908 \\
3,130 \\
3,352 \\
3,574 \\
3,796\end{array}$ & $\begin{array}{l}\mathrm{y} \equiv \mathrm{V} . \mathrm{C} . \\
\mathrm{a} \equiv \mathrm{Sit} . \mathrm{Ht} \text {. in } \mathrm{Cm} . \\
\mathrm{x} \equiv \mathbf{1 1 1} \\
\mathrm{b}=-6,083\end{array}$ & $\begin{array}{l}76.6 \\
78.6 \\
80.5 \\
88.5 \\
84.4 \\
86.3\end{array}$ & $\begin{array}{l}2.18 \\
2.14 \\
2.09 \\
2.07 \\
1.93 \\
1.96\end{array}$ & $\begin{array}{l}23.3 \\
24.5 \\
26.2 \\
31.7 \\
35.5 \\
46.4\end{array}$ & $\begin{array}{l}287 \\
346 \\
383 \\
362 \\
317 \\
328\end{array}$ & $\begin{array}{l}10.7 \\
12.0 \\
12.3 \\
12.4 \\
8.8 \\
11.4\end{array}$ \\
\hline $\begin{array}{r}16 \\
6 \\
4\end{array}$ & $\begin{array}{l}91 \\
93 \\
95\end{array}$ & $\begin{array}{l}3,913 \\
4,142 \\
4,275\end{array}$ & $\begin{array}{l}3,967 \\
4,123 \\
4,275\end{array}$ & $\begin{array}{l}171 \\
156 \\
152\end{array}$ & $\begin{array}{l}4.5 \\
3.9 \\
3.7\end{array}$ & $\begin{array}{l}3,967 \\
4,119 \\
4,273\end{array}$ & $\begin{array}{l}\mathrm{y}=\mathrm{V} . \text { C. } \\
\mathrm{a} \equiv \text { Sit. Ht. in Cm. } \\
\mathrm{x}=76.5 \quad \mathrm{~b}=-2,994\end{array}$ & $\begin{array}{l}88.3 \\
90.2 \\
92.2\end{array}$ & $\begin{array}{l}1.97 \\
1.97 \\
1.99\end{array}$ & & & \\
\hline
\end{tabular}


table 8.-Normal Girls. Number of Cases, Sitting Height, Average Vital. Capacity, Vital Capacity as Determined by Graphic Interpolation, Absolute and Percentage Increase in Vital Capacity Accompanying Each 2 Cm. Growth in Stey Levgth, Vital Capacity as Computed froy Sitting Height by Formula, with Formula Used in Computrng the Vital Capacity, Corrected Sitting Height and Values Derived from Formula, Souare of Sitting Height in Cm., Probable Error, Standard Deviation, and Coefficient Variation

\begin{tabular}{|c|c|c|c|c|c|c|c|c|c|c|c|c|}
\hline $\begin{array}{c}\text { Number } \\
\text { of } \\
\text { Cases }\end{array}$ & $\begin{array}{l}\text { Sitting } \\
\text { Height, } \\
\text { Cm. }\end{array}$ & $\begin{array}{c}\text { Average } \\
\text { vital } \\
\text { Capacity, } \\
\text { C.e. }\end{array}$ & $\begin{array}{c}\text { Mean Vital } \\
\text { Capacity } \\
\text { as } \\
\text { Determined } \\
\text { by } \\
\text { Graphic } \\
\text { Interpo- } \\
\text { lation. } \\
\text { C.e. }\end{array}$ & $\begin{array}{l}\text { Absolute } \\
\text { Inerease in } \\
\text { Vital Ca- } \\
\text { paeity with } \\
\text { Each } 2 \text { Cm. } \\
\text { Growth in } \\
\text { Standing } \\
\text { Height, } \\
\text { Cm. }\end{array}$ & $\begin{array}{c}\text { Percentage } \\
\text { Yearly } \\
\text { Inerease in } \\
\text { V. C. with } \\
\text { Each } 2 \mathrm{Cm} . \\
\text { Growth in } \\
\text { Standing } \\
\text { Height, } \\
\text { Cm. }\end{array}$ & $\begin{array}{c}\text { Vital } \\
\text { Capaeity } \\
\text { as } \\
\text { Computed } \\
\text { by } \\
\text { Formula } \\
y=(a x) \pm b\end{array}$ & $\begin{array}{l}\text { Formula Used for } \\
\text { Each Sitting Height } \\
\text { (roup } \\
y=(\mathrm{ax}) \pm b\end{array}$ & $\begin{array}{l}\text { Cor- } \\
\text { rected } \\
\text { Sitting } \\
\text { Height }\end{array}$ & $\frac{\text { S. H. }{ }^{2}}{\text { v. C. }}$ & $\begin{array}{c}\text { Probable } \\
\text { Error of } \\
\text { Random } \\
\text { Sampling. } \\
\text { C.c. }\end{array}$ & $\begin{array}{c}\text { Standard } \\
\text { Devia- } \\
\text { tion, } \\
\text { C.e. }\end{array}$ & $\begin{array}{l}\text { Coeftl- } \\
\text { elent of } \\
\text { Varia- } \\
\text { tion. } \\
\text { per Cent. }\end{array}$ \\
\hline $\begin{array}{r}1 \\
2 \\
10 \\
31 \\
48 \\
44\end{array}$ & $\begin{array}{l}51 \\
53 \\
55 \\
57 \\
59 \\
61\end{array}$ & $\begin{array}{r}750 \\
1,050 \\
940 \\
908 \\
1,107 \\
1.205\end{array}$ & $\begin{array}{r}750 \\
860 \\
956 \\
1,038 \\
1,128 \\
1,236\end{array}$ & $\begin{array}{l}+110 \\
+96 \\
+82 \\
+90 \\
+108\end{array}$ & $\begin{array}{l}13.7 \\
11.2 \\
8.6 \\
8.7 \\
9.6\end{array}$ & $\begin{array}{r}750 \\
847 \\
944 \\
1.042 \\
1.139 \\
1,236\end{array}$ & $\begin{array}{c}(48.6 \times \text { Ht. })-1,728= \\
\text { V. C. }\end{array}$ & $\begin{array}{l}49.5 \\
51.4 \\
53.3 \\
55.3 \\
57.2 \\
59.2\end{array}$ & $\begin{array}{l}3.27 \\
3.08 \\
3.02 \\
2.95 \\
2.90 \\
2.84\end{array}$ & $\begin{array}{l}21.5 \\
12.7 \\
13.7\end{array}$ & $\begin{array}{l}177 \\
131 \\
159\end{array}$ & $\begin{array}{l}17.7 \\
11.8 \\
13.2\end{array}$ \\
\hline $\begin{array}{l}71 \\
78 \\
69 \\
74 \\
67 \\
57 \\
77\end{array}$ & $\begin{array}{l}68 \\
65 \\
67 \\
69 \\
71 \\
73 \\
75\end{array}$ & $\begin{array}{l}1,386 \\
1,469 \\
1,636 \\
1,759 \\
1,881 \\
1,952 \\
2,113\end{array}$ & $\begin{array}{l}1,360 \\
1,492 \\
1,621 \\
1,747 \\
1,867 \\
1,991 \\
2,124\end{array}$ & $\begin{array}{l}+124 \\
+132 \\
+129 \\
+126 \\
+120 \\
+124 \\
+133\end{array}$ & $\begin{array}{r}10.0 \\
9.7 \\
86 \\
7.8 \\
6.9 \\
6.6 \\
6.6\end{array}$ & $\begin{array}{l}1,360 \\
1,490 \\
1,620 \\
1,751 \\
1,881 \\
2,011 \\
2,141\end{array}$ & $\begin{array}{l}(65.1 \times \text { Ht. })-2,741= \\
\text { V. C. }\end{array}$ & $\begin{array}{l}61.1 \\
63.1 \\
65.0 \\
66.9 \\
68.9 \\
71.8 \\
72.8\end{array}$ & $\begin{array}{l}2.75 \\
2.67 \\
2.61 \\
2.56 \\
2.54 \\
2.52 \\
2.49\end{array}$ & $\begin{array}{l}10.7 \\
12.1 \\
17.3 \\
16.1 \\
18.2 \\
15.6 \\
17.1\end{array}$ & $\begin{array}{l}133 \\
159 \\
213 \\
205 \\
221 \\
175 \\
224\end{array}$ & $\begin{array}{r}9.6 \\
10.8 \\
13.0 \\
11.7 \\
11.7 \\
9.0 \\
10.6\end{array}$ \\
\hline $\begin{array}{r}71 \\
107 \\
91 \\
89 \\
71\end{array}$ & $\begin{array}{l}77 \\
79 \\
81 \\
83 \\
85\end{array}$ & $\begin{array}{l}2,256 \\
2,458 \\
2,537 \\
2,740 \\
2,847\end{array}$ & $\begin{array}{l}2.271 \\
2,420 \\
2,568 \\
2,709 \\
2,843\end{array}$ & $\begin{array}{l}+147 \\
+149 \\
+148 \\
+149 \\
+134\end{array}$ & $\begin{array}{l}6.9 \\
6.6 \\
6.1 \\
5.8 \\
4.9\end{array}$ & $\begin{array}{l}2,279 \\
2,420 \\
2,561 \\
2,702 \\
2,843\end{array}$ & $(70.5 \times \underset{\text { H. }}{\text { V. }})-3,149=$ & $\begin{array}{l}74.7 \\
76.6 \\
78.6 \\
80.5 \\
82.5\end{array}$ & $\begin{array}{l}2.46 \\
2.43 \\
2.41 \\
2.39 \\
2.43\end{array}$ & $\begin{array}{l}20.5 \\
208 \\
18.5 \\
22.1 \\
22.4\end{array}$ & $\begin{array}{l}256 \\
317 \\
261 \\
309 \\
282\end{array}$ & $\begin{array}{r}11.3 \\
12.9 \\
10.3 \\
11.3 \\
9.9\end{array}$ \\
\hline $\begin{array}{l}30 \\
11 \\
1\end{array}$ & $\begin{array}{l}87 \\
89 \\
91\end{array}$ & $\begin{array}{l}2,967 \\
3,141 \\
3,100\end{array}$ & $\begin{array}{l}2,956 \\
3,040 \\
3,100\end{array}$ & $\begin{array}{r}+113 \\
+\quad 94 \\
+\quad 60\end{array}$ & $\begin{array}{l}3.9 \\
3.2 \\
2.0\end{array}$ & $\begin{array}{l}2,956 \\
3,028 \\
3,100\end{array}$ & $(36 \times \underset{\text { Ht. })}{\text { V. C. }}+176=$ & $\begin{array}{l}84.4 \\
86.3 \\
88.3\end{array}$ & $\begin{array}{l}2.41 \\
2.45 \\
2.51\end{array}$ & 44.3 & 359 & 12.1 \\
\hline
\end{tabular}


sitting height. For both sexes, however, the total relative increase in vital capacity exceeds that for the stem length. Dreyer claims that the vital capacity is related to the square of the sitting height. Whether or not this applies to the period of childhood will be considered later.

The curves of vital capacity as plotted against sitting height are somewhat irregular when drawn from the actual averages. In order to eliminate the minor fluctuations they have been smoothed by means of graphic interpolation (Fig. 3). The means for the vital capacity derived in this manner for each sitting height are recorded in Tables 7 and 8 .

In general, the smoothed curves plotted against stem length for each sex are quite similar to those plotted against either age or standing height, showing at first a phase of fairly uniform increase in vital

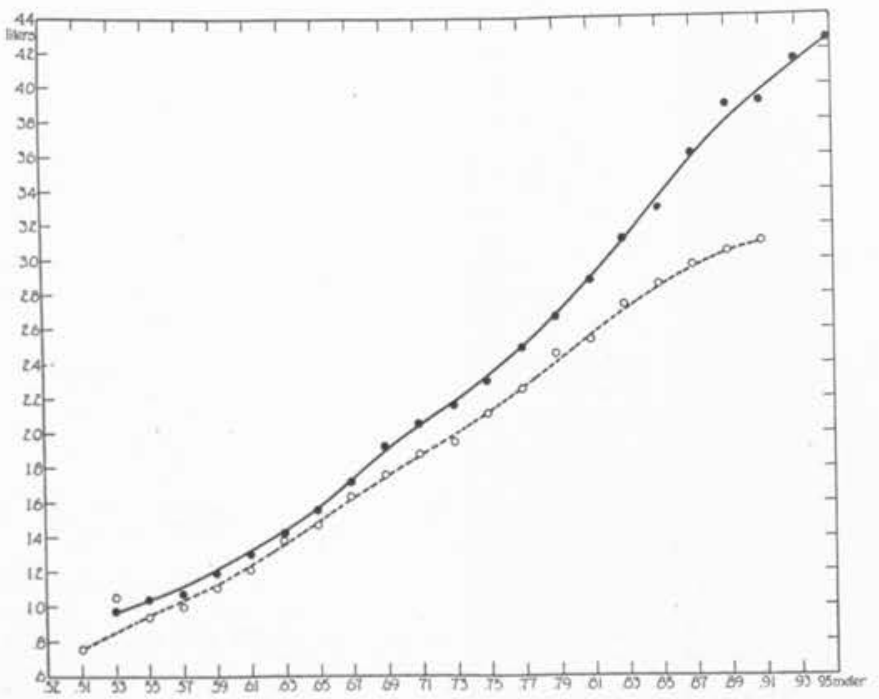

Fig. 3.-Showing smoothed curves representing the average absolute increase in the vital capacity of the lungs as determined by graphic interpolation, for boys with an increase in sitting height from 0.53 to 0.95 meters inclusive and for girls with an increase in sitting height from 0.51 to 0.91 meters inclusive. The actual observed averages at each stem length are respresented by dots for the boys and by circles for the girls. Vital capacity in liters is represented on the ordinate, and sitting height in meters on the abscissa.

capacity, followed by one of more rapid increase, and finally enters a phase of greater retardation in rate of growth of lung capacity. On the whole, the curves tend to assume a concave form throughout the greater extent of their course, the concavity being more marked with the boys than with the girls. At corresponding sitting height the curves show clearly a greater vital capacity for the boys than for the girls, the difference tending to increase as the growth in stem length occurs. 
The absolute increase in vital capacity which accompanies each $2 \mathrm{~cm}$. increase in sitting height (Tables 7 and 8 ) is fairly uniform for each sex at stem lengths ranging from 63 to $75 \mathrm{~cm}$. At this point the absolute increase tends to rise reaching a maximum of 238 c.c. for the boys and $149 \mathrm{c.c}$. for the girls, at stem lengths of 85 and $79 \mathrm{~cm}$., respectively. With each further increase of $2 \mathrm{~cm}$. in sitting height the gain in vital capacity for each sex progressively diminishes.

The relative increase per $2 \mathrm{~cm}$. growth in sitting height, in general, appears to diminish at first as the stem length increases, reaching a minimum of 6.8 and 6.6 per cent. for the boys and girls, respectively, at $73 \mathrm{~cm}$. sitting height. Subsequently, the relative rate of increase in vital capacity rises slightly with the boys to about 7.7 per cent. when the average sitting height is $85 \mathrm{~cm}$., but later declines again. With the girls the tendency for the relative increase in lung capacity to rise after an earlier period of decline is much less pronounced. It appears, however, that the rapidity of the decline in rate of percentage gain in vital capacity is greatly retarded at sitting heights ranging from 73 to $81 \mathrm{~cm}$.

The relation between sitting height and vital capacity has been fully discussed by Dreyer. ${ }^{20}$ This investigator states that the relationship between these two measurements may be expressed correctly by the formula $\frac{\mathrm{SH}^{n}}{\mathrm{C} .}=\mathrm{K}$, where $\mathrm{SH}=$ stem length in centimeters, V.C. $=$ vital capacity in cubic centimeters, the power $n$ is approximately 2 , and $\mathrm{K}$ is a constant. In other words, the vital capacity is related to the square of the sitting height. Dreyer bases this opinion on an analysis of the data of Hutchinson and Schuster, on sixteen personal observations, which to a large extent included observations mainly on adults. The average value for the constant obtained by Dreyer when derived in the above manner is 1.9 for males.

Dreyer measured the stem length by a special technic, seating the subject on the floor with his back against a perpendicular triangular projection, to which a scale is attached. On account of the influence of the muscles, the stem length taken when the subject is seated on a chair is found to be about 3 per cent. greater than those obtained by the method Dreyer used. Since the sitting heights for the children reported in this paper were obtained with the subjects seated on a chair, against a perpendicular wall, it is necessary to reduce my averages 3 per cent. to render them directly comparable with the measurements by Dreyer. The corrected sitting heights are recorded in Tables 7 and 8 .

The values for $\mathrm{K}$ with the boys (Table 7 ) as derived from the averages of vital capacity for each corrected sitting height during childhood are by no means a constant. The results obtained show a gradual decrease from an average of 2.71 to 1.93 with an increase in sitting height from 53 to $87 \mathrm{~cm}$. With further growth in stem length 
the value determined for $\mathrm{K}$ remains practically constant, possibly tending to increase slightly as sitting height increases. It is evident, therefore, that the formula $\frac{\mathrm{SH}^{2}}{\mathrm{~V} . \mathrm{C}}=\mathrm{K}$ is not a correct expression of the relation between the vital capacity and sitting height for the boys. Apparently this relation is not fully established until well into the latter half of childhood. At this period my data for children give a constant (1.93) which is very close to that obtained by Dreyer (1.90) for adults.

With the girls accompanying a growth in stem length from 51 to $83 \mathrm{~cm}$., the values derived for $\mathrm{K}$ decrease from 3.27 to 2.39 , but subsequently remains fairly constant.

It is evident, therefore, that a constant relation between the square of the sitting height and vital capacity also does not exist with the girls in early childhood, and apparently is not established until the girls obtain a sitting height of approximately $79 \mathrm{~cm}$.

The higher values for the constant with the girls, indicates a relatively smaller vital capacity of the lungs for them than for the boys.

The probable error of random sampling (Tables 7 and 8 ), as determined for the averages based on sitting height, is comparatively small. In general, for each sex, it apparently tends to increase constantly as sitting height and vital capacity increases.

The standard deviations recorded in Tables 7 and 8 resemble those obtained when the cases are grouped on different basis, tending to increase as vital capacity increases, and averaging higher, as a rule, with the boys than with the girls of corresponding stem length. As for relative variability (coefficients of variation; Tables 7 and 8 ) there is an apparent decrease in its extent with the shorter groups as they increase in stem length, followed by a later period where variability rises to some extent, and, finally, by a period during which it falls again. For the most part, the coefficients range between 10 and 14 . In general, then, the degree of variability in relation to the averages as based on stem length is quite similar to that observed with averages based on standing height.

If the observations at each age are distributed in groups differing $2 \mathrm{~cm}$. in stem length, as is done in Tables 9 and 10 , some conception of the variation in vital capacity at any age accompanying differences in stem length can be easily detected. The averages in these tables show that the vital capacities at every age are higher, as a rule, for the children with the greater stem length. When we consider, however, the average vital capacity for the children of similar sitting height but varying in age the differences are much less striking and constant.

5. Vital Capacity and Body Weight.-To study the relation between vital capacity and body weight, the data are averaged in Tables 11 and 12 in such manner that each group included subjects who varied not more than 5 pounds in body weight (including clothing). 
table 9.-Vital Capacity, in Cubic Centimeters, of Normal Boys for Every 2 Cm. Diffekence in Sitting Height at Each Age, and Average Vital. Capacity for Each 2 Cm. Growth in Stem Length, Combining All. Ages

\begin{tabular}{|c|c|c|c|c|c|c|c|c|c|c|c|c|c|c|c|c|c|c|c|c|c|c|}
\hline \multirow{2}{*}{ Age in Years } & \multicolumn{22}{|c|}{ Sitting Height } \\
\hline & 53 & 55 & 57 & 59 & 61 & .63 & 65 & 67 & 69 & $\pi 1$ & 73 & 75 & $\pi 7$ & 79 & 81 & 83 & 85 & 87 & 89 & 91 & 93 & 95 \\
\hline 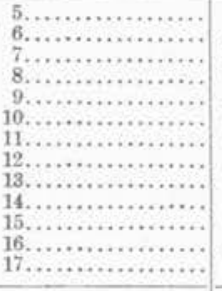 & $\begin{array}{r}950 \\
1,000 \\
\ldots . . \\
\ldots . . \\
\ldots . . \\
\ldots . . \\
\ldots . . \\
\ldots . . \\
\ldots . . \\
\ldots . . \\
\ldots . . \\
\end{array}$ & $\begin{array}{r}800 \\
1,125 \\
1,150 \\
\ldots \ldots . \\
\ldots \ldots . \\
\ldots . . \\
\ldots . . \\
\ldots . . \\
\ldots . . \\
\ldots \ldots . \\
\ldots \ldots . \\
\ldots . . \\
\end{array}$ & $\begin{array}{r}910 \\
1,061 \\
1,150 \\
1,200 \\
\ldots \ldots . \\
\ldots \ldots . \\
\ldots \ldots . \\
\ldots \ldots . \\
\ldots \ldots . \\
\ldots \ldots . \\
\ldots . . \\
\ldots . . \\
\end{array}$ & $\begin{array}{l}1,025 \\
1,172 \\
1,176 \\
1,300 \\
1,400 \\
\ldots \ldots . \\
\ldots \ldots . \\
\ldots \ldots . \\
\ldots \ldots . \\
\ldots \ldots . \\
\ldots \ldots . \\
\ldots . . . \\
\end{array}$ & $\begin{array}{l}1,008 \\
1,184 \\
1,300 \\
1,294 \\
1,517 \\
1,525 \\
\ldots \ldots . \\
\ldots \ldots . \\
\ldots \ldots . \\
\ldots \ldots . \\
\ldots \ldots . \\
\ldots . . \\
\end{array}$ & $\begin{array}{c}1,150 \\
1,329 \\
1,323 \\
1,424 \\
1,496 \\
1,817 \\
1,500 \\
\ldots \ldots . \\
\ldots \ldots . \\
\ldots \ldots . \\
\ldots . . \\
\ldots . .6 \\
\end{array}$ & $\begin{array}{l}1,200 \\
1,389 \\
1,556 \\
1,602 \\
1,679 \\
1,767 \\
1,700 \\
\ldots \ldots . \\
\ldots \ldots . \\
\ldots \ldots . \\
\ldots . . \\
\end{array}$ & $\begin{array}{l}\ldots . . \\
1,460 \\
1,632 \\
1,764 \\
1,728 \\
1,783 \\
1,850 \\
1,800 \\
\ldots \ldots . \\
\ldots \ldots . \\
\ldots \ldots . \\
\end{array}$ & $\begin{array}{l}\ldots . . \\
2,200 \\
1,825 \\
1,796 \\
1,920 \\
1,979 \\
1,950 \\
2,125 \\
\ldots \ldots . \\
\ldots \ldots . \\
\ldots \ldots . \\
\end{array}$ & $\begin{array}{c}\ldots . . \\
\ldots . . \\
\ldots \ldots . \\
1,995 \\
1,988 \\
2,088 \\
2,050 \\
2,069 \\
2,158 \\
\ldots \ldots . \\
\ldots \ldots . \\
\ldots . .6 \\
\end{array}$ & $\begin{array}{l}\ldots . . \\
\ldots . . . \\
\ldots \ldots . \\
\ldots . . \\
2,500 \\
2,031 \\
2,110 \\
2,144 \\
2,267 \\
2,100 \\
2,400 \\
\ldots \ldots . \\
\ldots . . \\
\end{array}$ & $\begin{array}{l}\ldots . . . \\
\ldots . . \\
\ldots \ldots . \\
2.5 . \\
2,500 \\
2,200 \\
2,177 \\
2,241 \\
2,310 \\
2,396 \\
2,311 \\
2,388 \\
\ldots \ldots . \\
\end{array}$ & $\begin{array}{l}\ldots . . \\
\ldots . . \\
\ldots \ldots . \\
\ldots \ldots . \\
2,6.6 \\
2,500 \\
2,406 \\
2,423 \\
2,512 \\
2,688 \\
2,450 \\
\ldots . . \\
\end{array}$ & $\begin{array}{l}\ldots . . \\
\ldots . . \\
\ldots . . \\
\ldots . . \\
\ldots . . \\
2,500 \\
2,650 \\
2,604 \\
2,659 \\
2,788 \\
2,675 \\
\ldots \ldots . \\
\end{array}$ & $\begin{array}{l}\ldots . . \\
\ldots . . \\
\ldots \ldots . \\
\ldots . . \\
\ldots . . \\
\ldots \ldots . \\
2,788 \\
2,814 \\
2,813 \\
2,926 \\
3,617 \\
\ldots \ldots . \\
\end{array}$ & $\begin{array}{l}\ldots . . \\
\ldots . . \\
\ldots \ldots . \\
\ldots . . \\
\ldots . . \\
\ldots \ldots . \\
2.800 \\
3.012 \\
3,023 \\
3,269 \\
3,186 \\
2,550 \\
\end{array}$ & $\begin{array}{l}\ldots . . . \\
\ldots . . . \\
\ldots \ldots . \\
\ldots . . \\
\ldots . . . \\
\ldots \ldots . \\
\ldots \ldots . \\
3,334 \\
3,221 \\
3,288 \\
3,373 \\
2,900 \\
\end{array}$ & $\begin{array}{l}\ldots . . \\
\ldots \ldots . \\
\ldots \ldots . \\
\ldots . . \\
\ldots . . \\
\ldots \ldots . \\
\ldots . . \\
\ldots \ldots . \\
3,395 \\
3,666 \\
3,606 \\
3,850 \\
\end{array}$ & $\begin{array}{l}\ldots . . \\
\ldots . . \\
\ldots . . \\
\ldots . . \\
\ldots \ldots . \\
\ldots . . \\
\ldots . . \\
4,0 . \\
3,000 \\
3,850 \\
3,953 \\
4,007 \\
4,000 \\
\end{array}$ & $\begin{array}{c}\ldots . . \\
\ldots . . \\
\ldots \ldots . \\
\ldots . . . \\
\ldots \ldots . \\
\ldots \ldots . \\
\ldots \ldots . \\
\ldots \ldots . \\
3,450 \\
3,769 \\
4,125 \\
4,167 \\
\end{array}$ & $\begin{array}{c}\ldots . . \\
\ldots . . \\
\ldots . . \\
\ldots . . \\
\ldots . . \\
\ldots . . \\
\ldots . . \\
\ldots . . \\
\ldots . . \\
\ldots \ldots . \\
4.300 \\
4,062 \\
\end{array}$ & $\begin{array}{c}\ldots . . \\
\ldots . . \\
\ldots . . . \\
\ldots \ldots . \\
\ldots \ldots . \\
\ldots \ldots . \\
\ldots \ldots . \\
\dddot{2} . . . \\
4,250 \\
\ldots .300 \\
4,300 \\
\end{array}$ \\
\hline Average............ & 975 & 1,036 & 1,071 & 1,190 & 1,302 & 1,425 & 1,557 & 1,719 & 1,923 & 2,054 & 2,159 & 2,300 & 2,497 & 2,671 & 2,881 & 3.104 & $\overline{3,292}$ & 3,607 & 3,897 & $\overline{3,913}$ & 4,142 & 4,275 \\
\hline
\end{tabular}

table 10.-Vital Capacity, in Cubic Centimeters, of Normal Girls, for Every 2 Cm. Difference in Sitting at Each Age, and Average Vtal. Capacity for Each 2 Cm. Growth in Stem Length, Combining All Ages

\begin{tabular}{|c|c|c|c|c|c|c|c|c|c|c|c|c|c|c|c|c|c|c|c|c|c|}
\hline \multirow{2}{*}{ Age in Years } & \multicolumn{21}{|c|}{ Sitting Height } \\
\hline & 51 & 53 & 55 & 57 & 59 & 61 & 63 & 65 & 67 & 69 & $\pi 1$ & 73 & 75 & 77 & 79 & 81 & 83 & 85 & 87 & 89 & 91 \\
\hline 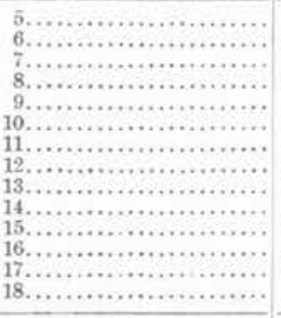 & $\begin{array}{l}750 \\
\ldots \ldots . \\
\ldots \ldots . \\
\ldots \ldots . \\
\ldots \ldots . \\
\ldots \ldots . \\
\ldots \ldots . \\
\ldots \ldots . \\
\ldots \ldots . \\
\ldots \ldots . \\
\ldots \ldots . \\
\end{array}$ & 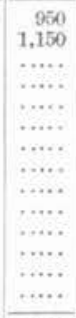 & $\begin{array}{c}867 \\
983 \\
900^{-} \\
\ldots \ldots . \\
\ldots \ldots . \\
\ldots \ldots . \\
\ldots \ldots . \\
\ldots \ldots . \\
\ldots \ldots . \\
\ldots \ldots . \\
\ldots \ldots . \\
\ldots \ldots \\
\end{array}$ & $\begin{array}{r}859 \\
1,068 \\
1,094 \\
1,000 \\
\ldots \ldots . \\
\ldots \ldots . \\
\ldots \ldots . \\
\ldots \ldots . \\
\ldots \ldots . \\
\ldots \ldots . \\
\ldots \ldots . \\
\ldots \ldots . \\
\end{array}$ & $\begin{array}{l}1,067 \\
1,102 \\
1,098 \\
1,192 \\
1,167 \\
900 \\
\ldots \ldots . \\
\ldots \ldots . \\
\ldots \ldots . \\
\ldots \ldots . \\
\ldots \ldots . \\
\ldots \ldots . \\
\end{array}$ & 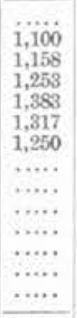 & $\begin{array}{l}1,250 \\
1,353 \\
1,415 \\
1,425 \\
1,404 \\
1,431 \\
1,450 \\
\cdots \cdots \\
\cdots \cdots \\
\ldots \ldots . \\
\ldots \ldots . \\
\cdots \cdots \\
\end{array}$ & $\begin{array}{l}1,266 \\
1,400 \\
1,474 \\
1,4 \cdot 3 \\
1,505 \\
1,612 \\
1,450 \\
1,700 \\
\ldots \ldots . \\
\ldots \ldots . \\
\ldots \ldots . \\
\ldots \ldots \\
\end{array}$ & $\begin{array}{l}\ldots \ldots . \\
1,325 \\
1,483 \\
1,540 \\
1,643 \\
1,609 \\
1,869 \\
1,600 \\
\ldots \ldots . \\
\ldots \ldots . \\
\ldots \ldots . \\
\ldots \ldots \\
\end{array}$ & $\begin{array}{l}\ldots \ldots . \\
1,700 \\
1,687 \\
1,738 \\
1,749 \\
1,773 \\
1,538 \\
1,933 \\
\ldots \ldots . \\
\ldots \ldots . \\
\ldots \ldots . \\
\ldots \ldots . \\
\end{array}$ & 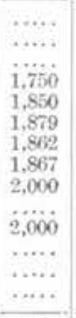 & $\begin{array}{l}\ldots \ldots . \\
\ldots \ldots . \\
\ldots \ldots . \\
2,000 \\
2,012 \\
1,943 \\
1,921 \\
1,933 \\
2,250 \\
2,000 \\
\ldots \ldots . \\
\ldots \ldots . \\
\end{array}$ & $\begin{array}{c}\ldots . . \\
\ldots \ldots . \\
\ldots \ldots . \\
\ldots \ldots . \\
\ldots, 175 \\
1,975 \\
2,102 \\
2,149 \\
2,230 \\
2,150 \\
\ldots \ldots . \\
\ldots \ldots . \\
\ldots \ldots \\
\end{array}$ & $\begin{array}{l}\ldots . . \\
\ldots . . \\
\ldots \ldots . \\
\ldots \ldots . \\
\ldots \ldots . \\
2,300 \\
2,050 \\
2,258 \\
2,236 \\
2,314 \\
2,240 \\
\ldots \ldots . \\
\ldots \ldots . \\
\ldots . . \\
\end{array}$ & $\begin{array}{l}\ldots . . . \\
\ldots . . \\
\ldots \ldots . \\
\ldots \ldots . \\
2,7.6 \\
2,117 \\
2,283 \\
2,437 \\
2,465 \\
2,567 \\
2,762 \\
\ldots \ldots . \\
\ldots . . \\
\end{array}$ & $\begin{array}{c}\ldots . . . \\
\ldots \ldots . \\
\ldots \ldots . \\
\ldots \ldots . \\
\ldots \ldots . \\
\ldots \ldots . \\
2,5 . \\
2,456 \\
2,595 \\
2,686 \\
2,512 \\
2,250 \\
\ldots \ldots \\
\end{array}$ & $\begin{array}{l}\ldots . . \\
\ldots \ldots . \\
\ldots \ldots . \\
\ldots \ldots . \\
\ldots \ldots . \\
\ldots \ldots . \\
2,700 \\
2,713 \\
2,716 \\
2,820 \\
2,550 \\
2,700 \\
\ldots \ldots \\
\end{array}$ & $\begin{array}{l}\ldots . . \\
\ldots . . \\
\ldots . . \\
\ldots \ldots . \\
\ldots \ldots . \\
\ldots \ldots . \\
\ldots \ldots . \\
2,967 \\
2,023 \\
2,846 \\
2,848 \\
3,017 \\
3,100 \\
\end{array}$ & $\begin{array}{c}\ldots . . \\
\ldots \ldots . \\
\ldots \ldots . \\
\ldots \ldots . \\
\ldots \ldots . \\
\ldots \ldots . \\
\ldots \ldots . \\
\ldots \ldots .8 \\
2,883 \\
2,958 \\
3,029 \\
3,012 \\
\ldots \ldots . \\
\ldots \ldots \\
\end{array}$ & $\begin{array}{c}\ldots . . \\
\ldots . . \\
\ldots \ldots . \\
\ldots \ldots . \\
\ldots \ldots . \\
\ldots \ldots . \\
\ldots \ldots . \\
\ldots \ldots . \\
\ldots, 2 . \\
3,225 \\
\ldots \ldots . \\
\ldots \ldots . \\
\ldots \ldots . \\
\end{array}$ & 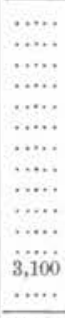 \\
\hline Average................. & 750 & 1,050 & 940 & 998 & 1,107 & 1,205 & 1,386 & 1,469 & 1,636 & 1,759 & 1.881 & 1,952 & 2,113 & 2,256 & 2,458 & 2,537 & 2,740 & 2,847 & 2,967 & 3,141 & 3,100 \\
\hline
\end{tabular}


For the boys (Table 11) with an increase in gross weight from 43 to 133 pounds the vital capacity increased from 1,157 to 3,635 c.c. Accompanying this increase in weight, amounting to 209 per cent., the vital capacity has increased 214 per cent. With the girls (Table 12) for a corresponding growth in weight, the lung capacity increases from 1,099 to 3,047 c.c., or 177 per cent. Thus, while with the boys the relative increase in vital capacity on the average exceeds that in weight, just the reverse is true for the girls.

Table 11.-Normal Boys. Number of Cases, Body Weight, Vital.

Capacity, Average Vital Capacity, Average Vital Capacity as

Determined by Graphic Interpolation. Absolute and Percentage

Increase in Vital Capacity, Vital. Capacity as Computed by For-

mula, with Formula Used, 0.72 Power of Weight in Grams aNd

Values Derived from Formula $\frac{\text { WO. } 72}{\text { V.C. }}$

\begin{tabular}{|c|c|c|c|c|c|c|c|c|c|}
\hline $\begin{array}{c}\text { No. } \\
\text { of } \\
\text { Cases }\end{array}$ & $\begin{array}{c}\text { Gross } A \\
\text { Wt. } \\
\text { in } \\
\text { Lbs. }\end{array}$ & $\begin{array}{l}\text { Average } \\
\text { vital } \\
\text { Capac- } \\
\text { ity, } \\
\text { C.c. }\end{array}$ & $\begin{array}{c}\text { Mean } \\
\text { Vital } \\
\text { Capac- } \\
\text { ity as } \\
\text { Deter- } \\
\text { mined } \\
\text { by } \\
\text { Graphic } \\
\text { Interpo- } \\
\text { lation, } \\
\text { C.c. }\end{array}$ & $\begin{array}{c}\text { Abso- } \\
\text { lute } \\
\text { Increase I } \\
\text { in Vital } \\
\text { Capac- } \\
\text { ity with } \\
\text { Each } \\
5 \text { Lbs. } \\
\text { Increase } \\
\text { in } \\
\text { Weight }\end{array}$ & $\begin{array}{c}\text { Per- } \\
\text { centage } \\
\text { Increase. } \\
\text { etc.; } \\
\text { with } \\
\text { Each } \\
5 \text { Lbs. } \\
\text { Increase } \\
\text { in Gross } \\
\text { Weight }\end{array}$ & $\begin{array}{c}\text { Vital } \\
\text { Capacity } \\
\text { as } \\
\text { Deter- } \\
\text { mined } \\
\text { by } \\
\text { Fmpirieal } \\
\text { Formula } \\
\mathrm{y}=\mathrm{ax} \pm \mathrm{b}\end{array}$ & $\begin{array}{l}\text { Empirical } \\
\text { Formula } \\
\mathrm{y}=(\mathrm{ax}) \pm \mathrm{b}\end{array}$ & W .72 & $\frac{\mathrm{w} \cdot 72}{\mathrm{v} \cdot \mathrm{c} .}$ \\
\hline $\begin{array}{r}2 \\
13 \\
75 \\
88\end{array}$ & $\begin{array}{l}33 \\
38 \\
43 \\
48\end{array}$ & $\begin{array}{r}988 \\
1,135 \\
1,157 \\
1,275\end{array}$ & $\begin{array}{r}968 \\
1,090 \\
1,198 \\
1,319\end{array}$ & $\begin{array}{l}\dddot{y} 02 \\
+108 \\
+121\end{array}$ & $\begin{array}{r}11.0 \\
9.9 \\
9.2\end{array}$ & $\begin{array}{r}988 \\
1,098 \\
1,208 \\
1,319\end{array}$ & $\begin{array}{l}\mathrm{y}=\mathrm{V} . \mathrm{C} . \text { in } \mathrm{Cm} . \\
\mathrm{x}=22.0 \\
\mathrm{~b}=+263 \\
\mathrm{a}=\mathrm{Wt} . \text { in Lbs. }\end{array}$ & $\begin{array}{r}942 \\
1,069 \\
1,163 \\
1,258\end{array}$ & $\begin{array}{l}0.953 \\
0.958 \\
0.955 \\
0.946\end{array}$ \\
\hline $\begin{array}{l}78 \\
82 \\
79 \\
97 \\
86 \\
74 \\
96 \\
60\end{array}$ & $\begin{array}{l}53 \\
58 \\
63 \\
68 \\
73 \\
78 \\
83 \\
88\end{array}$ & $\begin{array}{l}1,458 \\
1,607 \\
1,780 \\
1,926 \\
2,062 \\
2,160 \\
2,284 \\
2,506\end{array}$ & $\begin{array}{l}1,458 \\
1,611 \\
1,765 \\
1,910 \\
2,046 \\
2,178 \\
2,311 \\
2,443\end{array}$ & $\begin{array}{l}+139 \\
+153 \\
+154 \\
+155 \\
+136 \\
+132 \\
+133 \\
+132\end{array}$ & $\begin{array}{r}10.5 \\
10.5 \\
9.6 \\
8.8 \\
7.1 \\
6.5 \\
6.1 \\
5.7\end{array}$ & $\begin{array}{l}1,458 \\
1,598 \\
1,739 \\
1,879 \\
2,020 \\
2,160 \\
2,301 \\
2,441\end{array}$ & $\begin{array}{l}\mathrm{y}=\mathrm{V} \cdot \mathrm{C} . \\
\mathrm{a}=\mathrm{w} \mathrm{t} . \text { in Lbs. } \\
\mathrm{x}=28.1 \\
\mathrm{~b}=+30\end{array}$ & $\begin{array}{l}1,343 \\
1,433 \\
1,526 \\
1,606 \\
1,681 \\
1,764 \\
1,850 \\
1,931\end{array}$ & $\begin{array}{l}0.921 \\
0.896 \\
0.866 \\
0.857 \\
0.833 \\
0.812 \\
0.804 \\
0.790\end{array}$ \\
\hline $\begin{array}{l}51 \\
45 \\
63 \\
41 \\
38 \\
36 \\
32\end{array}$ & $\begin{array}{r}93 \\
98 \\
103 \\
108 \\
113 \\
118 \\
125\end{array}$ & $\begin{array}{l}2,542 \\
2,687 \\
2,867 \\
2,922 \\
3,176 \\
3,318 \\
3,397\end{array}$ & $\begin{array}{l}2,574 \\
2,704 \\
2,841 \\
2,987 \\
3,142 \\
3,297 \\
3,443\end{array}$ & $\begin{array}{l}+131 \\
+130 \\
+137 \\
+146 \\
+155 \\
+155 \\
+146\end{array}$ & $\begin{array}{l}5.4 \\
5.1 \\
5.1 \\
5.1 \\
5.2 \\
4.9 \\
4.4\end{array}$ & $\begin{array}{l}2,574 \\
2,710 \\
2,845 \\
2,982 \\
3,118 \\
3,254 \\
3,443\end{array}$ & $\begin{array}{l}\mathrm{y}=\mathrm{V} . \mathrm{C} . \text { in C.e. } \\
\mathrm{a}=\mathrm{wt} . \text { in Lbs. } \\
\mathrm{x}=27.2 \\
\mathrm{~b}=+44\end{array}$ & $\begin{array}{l}2,014 \\
2,091 \\
2,171 \\
2,247 \\
2,332 \\
2,410 \\
2,493\end{array}$ & $\begin{array}{l}0.783 \\
0.772 \\
0.763 \\
0.754 \\
0.740 \\
0.733 \\
0.724\end{array}$ \\
\hline $\begin{array}{r}27 \\
17 \\
27 \\
13 \\
9 \\
8\end{array}$ & $\begin{array}{l}128 \\
133 \\
138 \\
143 \\
148 \\
158\end{array}$ & $\begin{array}{l}3,696 \\
3,685 \\
3,745 \\
3,815 \\
4,217 \\
4,181\end{array}$ & $\begin{array}{l}3,565 \\
3,680 \\
3,794 \\
3,929 \\
4,957 \\
4,181\end{array}$ & $\begin{array}{l}+122 \\
+115 \\
+114 \\
+135 \\
+128 \\
+110\end{array}$ & $\begin{array}{l}3.5 \\
3.2 \\
3.1 \\
3.3 \\
3.3 \\
2.7\end{array}$ & $\begin{array}{l}3,565 \\
3,690 \\
3,816 \\
3,941 \\
4,067 \\
4,183\end{array}$ & $\begin{array}{l}\mathrm{y}=\mathrm{V} . \mathrm{C} \cdot \text { in } \mathrm{C} . \mathrm{c} . \\
\mathrm{a} \equiv \mathrm{W} \mathrm{t} . \text { in Lbs. } \\
\mathrm{x} \equiv 25.1 \\
\mathrm{~b}=+343\end{array}$ & $\begin{array}{l}2,503 \\
2,629 \\
2,710 \\
2,795 \\
2,861 \\
2,932\end{array}$ & $\begin{array}{l}0.721 \\
0.714 \\
0.713 \\
0.709 \\
0.704 \\
0.701\end{array}$ \\
\hline
\end{tabular}

$\cdot \mathrm{W}=0.72$ power of the net weight in grams.

The straightened curves derived for vital capacity when averaged for weight are somewhat different in character than those previously described. With the boys the smoothed curve (Fig. 4) shows much less sinuosity than the curves plotted either against age, standing and sitting height. As for the girls the curve based on weight is definitely convex in character, and thus altogether different from those derived from averages determined on the other measurements. The convexity 
apparently due to the increase in vital capacity occurring at a relatively slower rate than increase in weight during later childhood. As in the case of the curves based on age, standing and sitting height, likewise those plotted against weight may be subdivided into different portions in such manner that each conforms closely to a straight line. It follows, therefore, that the vital capacity may be computed from the body weight by means of the same empirical formula used for the other curves.

Table 12.-Normal Girls, Number of Cases, Body Weight, Vital Capacity, Average Vital Capacity, Average Vital Capacity as Determined by Graphic Interpolation. Absolute and Percentage Increase in Vital Capacity, Vital. Capacity as Computed by ForMUla, With Formula Used, 0.72 POWER OF Weight in Grams and VALUES DERTVED From Formula W. W.

\begin{tabular}{|c|c|c|c|c|c|c|c|c|c|}
\hline $\begin{array}{c}\text { No. } \\
\text { of } \\
\text { Cases }\end{array}$ & $\begin{array}{c}\text { Gross } \\
\text { Wt. } \\
\text { in } \\
\text { Lbs. } \\
\text { In- } \\
\text { clud- } \\
\text { ing } \\
\text { Cloth- } \\
\text { ing }\end{array}$ & $\begin{array}{l}\text { Aver- } \\
\text { age } \\
\text { Vital } \\
\text { Capac- } \\
\text { ity, } \\
\text { C.c. }\end{array}$ & $\begin{array}{c}\text { Average } \\
\text { Vital } \\
\text { Oapac- } \\
\text { ity as } \\
\text { Deter- } \\
\text { mined } \\
\text { by } \\
\text { Graphic } \\
\text { Interpo- } \\
\text { lation, } \\
\text { C.c. }\end{array}$ & $\begin{array}{c}\text { Abso- } \\
\text { lute } \\
\text { Increase } \\
\text { in } \\
\text { vital } \\
\text { Capac- } \\
\text { ley with } \\
\text { Increase } \\
\text { in } \\
\text { Weight }\end{array}$ & $\begin{array}{c}\text { Per- } \\
\text { centage } \\
\text { of } \\
\text { Increase } \\
\text { in Vital } \\
\text { Capacity } \\
\text { with } \\
\text { Increase } \\
\text { in } \\
\text { Weight }\end{array}$ & $\begin{array}{c}\text { Vital } \\
\text { Capacity } \\
\text { as } \\
\text { Com. } \\
\text { puted } \\
\text { from } \\
\text { Formula } \\
\begin{array}{l}\mathrm{y}=(\mathrm{ax}) \\
\pm \mathrm{b}\end{array}\end{array}$ & $y \stackrel{\text { Formula }}{=}(\mathrm{ax}) \pm \mathrm{b}$ & W 0.72 & $\frac{{ }^{*} \mathrm{~W} .72}{\mathrm{~V} \cdot \mathrm{C} .}$ \\
\hline $\begin{array}{l}30 \\
54 \\
63 \\
86 \\
76 \\
74\end{array}$ & $\begin{array}{l}38 \\
43 \\
48 \\
53 \\
58 \\
63\end{array}$ & $\begin{array}{r}930 \\
1,009 \\
1,244 \\
1,388 \\
1,527 \\
1,651\end{array}$ & $\begin{array}{r}980 \\
1,066 \\
1,287 \\
1,382 \\
1,521 \\
1,656\end{array}$ & $\begin{array}{l}\dddot{+156} \\
+151 \\
+145 \\
+135 \\
+132\end{array}$ & $\begin{array}{r}13.8 \\
16.8 \\
11.7 \\
9.8 \\
8.7\end{array}$ & $\begin{array}{r}980 \\
1,075 \\
1,220 \\
1,365 \\
1,510 \\
1,655\end{array}$ & $\begin{array}{l}\mathrm{y}=\mathrm{V} \cdot \mathrm{C} . \\
\mathrm{a}=\mathrm{w} \mathrm{t} . \text { in I.bs. } \\
\mathrm{x}=29 \\
\mathrm{~b}=-172\end{array}$ & $\begin{array}{l}1,069 \\
1,163 \\
1,263 \\
1,356 \\
1,446 \\
1,570\end{array}$ & $\begin{array}{l}1.149 \\
1.069 \\
1.042 \\
0.999 \\
0.968 \\
0.918\end{array}$ \\
\hline $\begin{array}{l}68 \\
78 \\
60 \\
61 \\
69 \\
64 \\
64\end{array}$ & $\begin{array}{l}68 \\
73 \\
78 \\
83 \\
88 \\
93 \\
98\end{array}$ & $\begin{array}{l}1,798 \\
1,918 \\
2,029 \\
2,207 \\
2,271 \\
2,428 \\
2,520\end{array}$ & $\begin{array}{l}1,788 \\
1,917 \\
2,046 \\
2,170 \\
2,292 \\
2,406 \\
2,509\end{array}$ & $\begin{array}{l}+129 \\
+129 \\
+124 \\
+122 \\
+114 \\
+103 \\
+84\end{array}$ & $\begin{array}{l}7.8 \\
7.2 \\
6.5 \\
6.0 \\
5.2 \\
4.5 \\
3.5\end{array}$ & $\begin{array}{l}1,788 \\
1,908 \\
2,028 \\
2,148 \\
2,208 \\
2,388 \\
2,508\end{array}$ & $\begin{array}{l}\mathrm{y}=\mathrm{v} . \mathrm{O} . \\
\mathrm{a}=\mathrm{w} \mathrm{t} . \text { in } \mathrm{Lbs} . \\
\mathrm{x}=24 \\
\mathrm{~b}=+156\end{array}$ & $\begin{array}{l}1,624 \\
1,713 \\
1,800 \\
1,885 \\
1,987 \\
2,047 \\
2,132\end{array}$ & $\begin{array}{l}0.914 \\
0.900 \\
0.887 \\
0.879 \\
0.878 \\
0.860 \\
0.850\end{array}$ \\
\hline $\begin{array}{l}57 \\
48 \\
36 \\
32 \\
28 \\
15 \\
15 \\
14\end{array}$ & $\begin{array}{l}108 \\
108 \\
113 \\
118 \\
123 \\
128 \\
133 \\
138\end{array}$ & $\begin{array}{l}2,620 \\
2,720 \\
2,628 \\
2,808 \\
2,900 \\
3,037 \\
3,047 \\
3,061\end{array}$ & $\begin{array}{l}2,593 \\
2,660 \\
2,728 \\
2,805 \\
2,894 \\
2,972 \\
3,027 \\
3,061\end{array}$ & $\begin{array}{l}+67 \\
+68 \\
+77 \\
+\quad 89 \\
+78 \\
+\quad 55 \\
+34 \\
+\quad 34\end{array}$ & $\begin{array}{l}2.7 \\
2.6 \\
2.8 \\
3.3 \\
2.8 \\
1.9 \\
1.1 \\
1.1\end{array}$ & $\begin{array}{l}2,598 \\
2,660 \\
2,727 \\
2,794 \\
2,861 \\
2,928 \\
2,995 \\
3,062\end{array}$ & $\begin{array}{l}y=v, C, \\
a \equiv w t, \text { in Lbs. } \\
x=13.4 \\
b=-1,213\end{array}$ & $\begin{array}{l}2,208 \\
2,291 \\
2,361 \\
2,527 \\
2,589 \\
2,663 \\
2,743\end{array}$ & $\begin{array}{l}0.851 \\
0.862 \\
0.867 \\
0.882 \\
0.884 \\
0.889 \\
0.896\end{array}$ \\
\hline $\begin{array}{r}6 \\
4 \\
4 \\
2 \\
28 \\
1\end{array}$ & $\begin{array}{l}143 \\
148 \\
158 \\
173 \\
123 \\
193\end{array}$ & $\begin{array}{l}2,725 \\
3,000 \\
3,388 \\
2,900 \\
2,900 \\
2,900\end{array}$ & 2,894 & +78 & 2.8 & 2,861 & & 2,589 & 0.884 \\
\hline
\end{tabular}

- $w=0.72$ power of the net weight in grams.

The actual values for the constants to be used for different weight groups may be determined by referring to Tables 11 and 12 . The vital capacities computed from formula agree fairly closely with the actual averages and also with those as determined by graphic interpolation.

Dreyer ${ }^{20}$ claims that the relation between the vital capacity and body weight may be correctly expressed by the formula $\frac{\mathrm{W}^{n}}{\sqrt[\mathrm{V} . \mathrm{C}]{ }}=\mathrm{K}$, where 
$W$ is the net weight in grams, V.C. = vital capacity in cubic centimeters, the power $\mathrm{n}$ is 0.72 , and $\mathrm{K}=\mathrm{a}$ constant. The average value obtained for $\mathrm{K}$ by Dreyer for data collected largely from male adults is 0.69 .

In order to compare this relationship to body weight for children with Dreyer's findings for adults it was first necessary to correct my weights for clothing. The net weight for my cases has been determined by computing the weight of the clothing and deducting this from the gross weight. In estimating the weight of clothing the factors published by Bardeen ${ }^{5}$ were used and the net weights obtained in this manner are tabulated in Tables 11 and 12 .

With the boys the values obtained for $\mathrm{K}$ by means of the formula $\underset{\text { v.c. }}{\mathrm{W}^{\text {t2 }}}=\mathrm{K}$ are seen to decrease constantly as growth in body weight

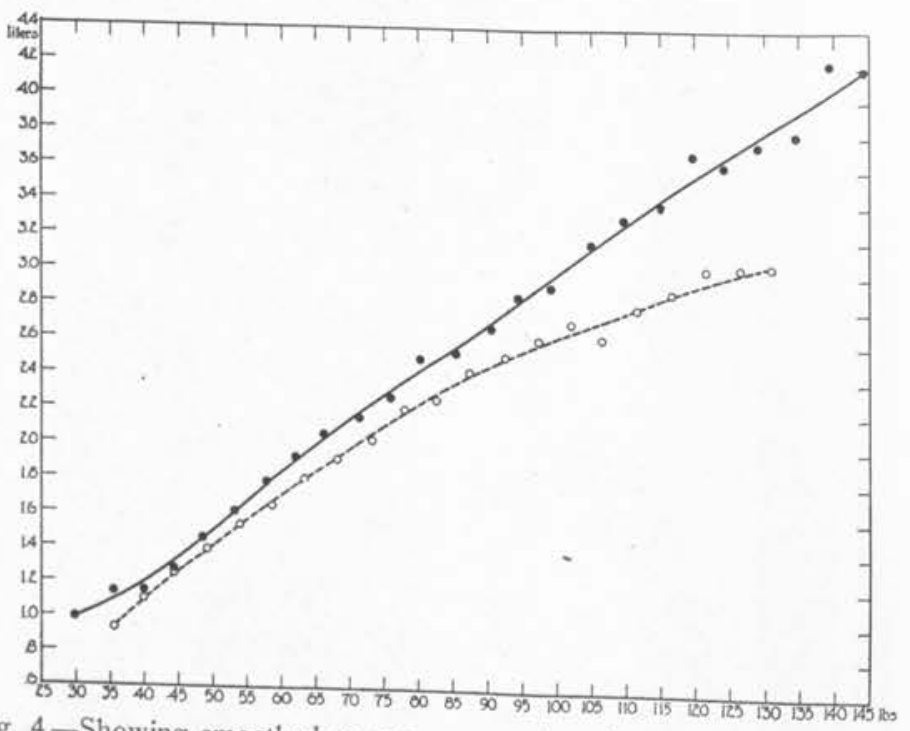

Fig. 4.-Showing smoothed curves representing the average absolute increase in the vital capacity of the lungs as determined by graphic interpolation for for girls with increase in net body weight from 30 to 145 pounds inclusive, and actual observed increase in body weight from 35 to 130 pounds inclusive. The the boys, and by circles for the net body weight are represented by dots for on the ordinate, and net capacity in liters is represented

occurs, diminishing from an average of 0.955 at a net weight of 40 pounds $(18,100 \mathrm{gm}$.$) to 0.701$ when weighing 143.8 pounds $(65,400$ gm.). This latter value, 0.701 , is quite similar to that $(0.69)$ obtained by Dreyer for adults. It is evident from these results that the constant relation between the 0.72 power of the weight and vital capacity is not established with boys until the net body weight is in the neighborhood
of 140 pounds. 
With the girls the value for $\mathrm{K}$ with an increase in net weight from 40 to 92 pounds decreases from 1.089 to 0.850 . With further increase in weight the value for $\mathrm{K}$ seems to increase slightly. For the girls also, then, the formula advocated by Dreyer is not a correct expression of the relation of vital capacity to body weight for children. It is not until the latter part of childhood that the above relation is fully established. At corresponding age, the values obtained for $\mathrm{K}$ (Tables 11 and 12) are higher for the girls than for the boys. It follows from this, as shown in numerous other instances, that lung capacity is relatively smaller for girls than for boys of similar size

TABle 13.-Number of Cases, Age, Weight, Standing Height, Vital Capacity, Normal Vital Capacity Expected for Corresponding

Standing Height, Per Cent. of Deviation from Normal, and Note Regarding Dyspnea for Boys and Girls with Mitral Regurgitation

\begin{tabular}{|c|c|c|c|c|c|c|c|}
\hline $\begin{array}{l}\text { Aver- } \\
\text { age } \\
\text { No, of } \\
\text { Cases }\end{array}$ & $\begin{array}{l}\text { Aver- } \\
\text { age } \\
\text { Age, } \\
\text { Years }\end{array}$ & $\begin{array}{l}\text { Aver- } \\
\text { age } \\
\text { Net } \\
\text { Weight, } \\
\text { Lbs. }\end{array}$ & $\begin{array}{l}\text { Aver- } \\
\text { age } \\
\text { Stand- } \\
\text { ing } \\
\text { Height. } \\
\text { Cm. }\end{array}$ & $\begin{array}{l}\text { Average } \\
\text { Vital } \\
\text { Capacity. } \\
\text { C.c. }\end{array}$ & $\begin{array}{l}\text { Average } \\
\text { Normal } \\
\text { Vital } \\
\text { Capacity } \\
\text { for Cor- } \\
\text { respond- } \\
\text { ing } \\
\text { Height, } \\
\text { C.c. }\end{array}$ & $\begin{array}{l}\text { Average } \\
\text { per Cent. } \\
\text { of } \\
\text { Deviation } \\
\text { from } \\
\text { Normal }\end{array}$ & Notes Regarding Dyspnea \\
\hline${ }_{8}^{\text {Boys }}$ & 11 & 74.6 & 142 & 2,131 & 2,182 & -2.4 & No dyspnea on exertion \\
\hline$\underset{17}{\text { Girls }}$ & 12 & 77.4 & 144 & 1,939 & 2,005 & -3.2 & No dyspnea on exertion \\
\hline $\begin{array}{c}\text { Boys } \\
1\end{array}$ & $\begin{array}{l}15 \\
11 \\
15 \\
16 \\
18\end{array}$ & $\begin{array}{r}57 \\
55 \\
61 \\
102 \\
122\end{array}$ & $\begin{array}{l}131 \\
138 \\
148 \\
162 \\
174\end{array}$ & $\begin{array}{r}900 \\
775 \\
1,600 \\
1,300 \\
1,350 \\
2,100\end{array}$ & $\begin{array}{l}1,160 \\
1,780 \\
1.850 \\
2,230 \\
3,180 \\
3,860\end{array}$ & $\begin{array}{l}-22.4 \\
-56.5 \\
-13.5 \\
-41.7 \\
-57.5 \\
-45.6\end{array}$ & $\begin{array}{l}\text { Spleen enlarged: moderate } \\
\text { dyspnea; rales in lungs } \\
\text { Dyspnea pronounced } \\
\text { Dyspnea on mild exertion } \\
\text { Dyspnea on slight exertion } \\
\text { Dyspnoic constantly } \\
\text { Dyspnea on slight exertion }\end{array}$ \\
\hline $\begin{array}{c}\text { Girls } \\
1 \\
2 \\
2 \\
3 \\
4 \\
5 \\
6 \\
7 \\
8 \\
9\end{array}$ & $\begin{array}{l}9 \\
11 \\
12 \\
11 \\
13 \\
13 \\
20 \\
14 \\
16\end{array}$ & $\begin{array}{r}40 \\
62 \\
52 \\
62 \\
87 \\
80 \\
117 \\
83 \\
190\end{array}$ & $\begin{array}{l}121 \\
129 \\
127 \\
129 \\
145 \\
146 \\
150 \\
152 \\
163\end{array}$ & $\begin{array}{r}950 \\
1,100 \\
900 \\
1,100 \\
900 \\
1,250 \\
1,500 \\
1,200 \\
1,950\end{array}$ & $\begin{array}{l}1.360 \\
1,580 \\
1,525 \\
1,590 \\
2,110 \\
2,150 \\
2,310 \\
2,400 \\
2,820\end{array}$ & $\begin{array}{r}-30.1 \\
-30.4 \\
-41.0 \\
-30.8 \\
-57.3 \\
-41.9 \\
-35.1 \\
-50.0 \\
-31.0\end{array}$ & $\begin{array}{l}\text { Dyspnole } \\
\text { Slight dyspnea } \\
\text { Mild dyspnea on exertion } \\
\text { Moderate dyspnea } \\
\text { Severe dyspnea } \\
\text { Moderate dyspnea } \\
\text { Moderate dyspnea } \\
\text { Dyspnea on slight exertion } \\
\text { Considerable dyspnea }\end{array}$ \\
\hline
\end{tabular}

Although the present investigation is devoted mainly to a consideration of the vital capacity of the lungs of normal and healthy children, a series of observations were made on a considerable number of subjects suffering from pathologic conditions of the heart and lungs. A brief discussion of the results obtained in each disease is given below.

6. Vital Capacity and Mitral Insufficiency.-Records were obtained for fourteen boys and twenty-six girls suffering from mitral insufficiency of varying degrees of severity (Table 13). The data for eight boys and seventeen girls show the vital capacity to average practically normal for their standing height in spite of the presence of a 
leaking mitral valve. These children, as a group, are able to play and romp almost as vigorously as normal children without suffering from dyspnea to any extent. With the more severe cases, however, the vital capacity is seen to be greatly reduced, the reduction in some cases amounting to more than 50 per cent., and in such instances dyspnea is a very prominent symptom. In general, it may be said, that the tendency to become dyspneic is directly proportional to the degree to which the vital capacity is reduced. Ruebow, ${ }^{14}$ Bittorf and Forschbach, ${ }^{23}$ Beebak, Bie and Maar, ${ }^{16}$ Plesch, ${ }^{17}$ Wilson and Edwards, ${ }^{24}$ and others have also noted the vital capacity to be reduced by diseases of the heart. Siebeck ${ }^{15}$ attributes the decrease in vital capacity in heart disease to a change in the elasticity of the lungs resulting from engorgement of the pulmonary circulation. From a study of 124 adults suffering from various types of heart disease, Peabody and Wentworth ${ }^{18}$ have decided that, in general, patients with a vital capacity of 90 per cent. or more of the normal standard adopted for their sex and height have little or no abnormal tendency to dyspnea. If reduced to 70 or 90 per cent. of the normal, dyspnea appears to be an unusual exertion, while if reduced to 40 or 70 per cent. of the normal the activities of these patients must be greatly restricted. Those with a vital capacity of less than 40 per cent. of the normal are usually confined to bed, and the mortality is high with this group.

Repeated observations made of a few children having mitral disease show that the vital capacity increases as the clinical condition improves. The record for one girl with mitral regurgitation and rheumatic fever is given in Figure 5. The record of a girl suffering from cardiac decompensation following a heavy day's work is given in Figure 6 . In each instance the vital capacity is seen to progressively increase, and the hospital records show a similar improvement in their condition clinically. With the older girl (Fig. 6) the reduction in vital capacity recorded on the twenty-sixth day of illness followed a tonsillectomy done two days previously. When dismissed from the hospital on the twenty-eighth day of illness the vital capacity recorded was considerably higher even than the normal expected for corresponding standing height.

Peabody and Wentworth and Ulrich and Nathanson ${ }^{25}$ also present records for adults that show fluctuations in the vital capacity to correspond with changes in the patient's condition. Periodic measure-

23. Bittorf, A, and Forschbach, J.: Untersuchungen über die Lungenfüllung bei Krankheiten, Ztschr. f. klin. Med, 70, 1910.

24. Wilson, M. G., and Edwards, D. J.: Standards for Normal Vital Capacity Dis. Child, 22:443 Lung Capacity in Certain Intrathoracic Conditions, Am. J. city of Lungs of Children, J. A. M. A. 78:1107 (April 15) 1922.
25. Ulrich,

25. Ulrich, H. L., and Nathanson, M. H.: The Capacity of the Lungs in
Cardiac Disease, Minnesota M. 4:721, 1921. 


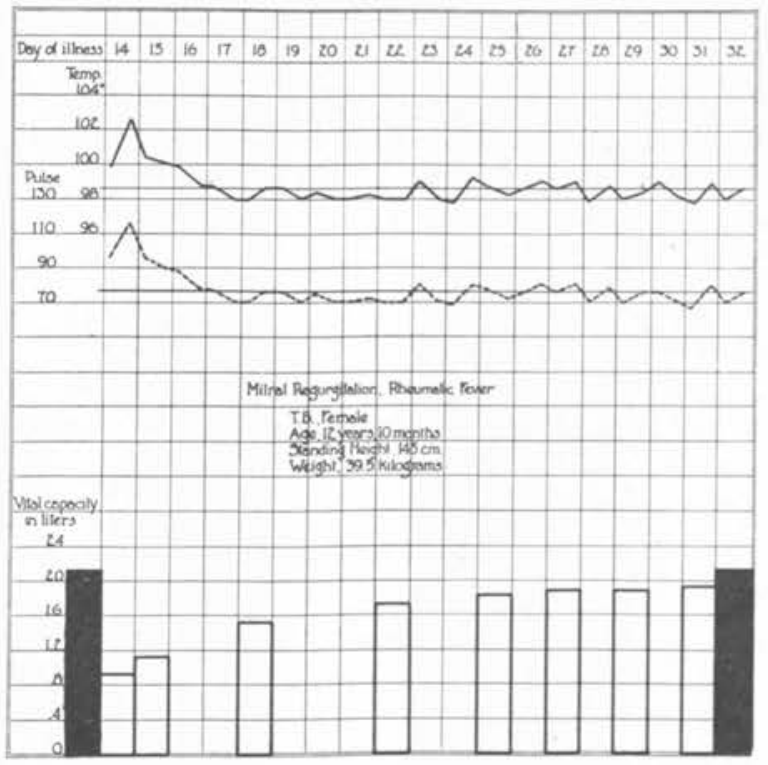

Fig. 5.-Showing the changes in body temperature, pulse rate, and vital capacity of the lungs from the fourteenth to the thirty-first day of illness, for a girl having acute rheumatic fever, and mitral regurgitation. The solid black rectangles represent the normal vital capacity for corresponding standing height; the blank rectangles represent the observed vital capacity on successive days.

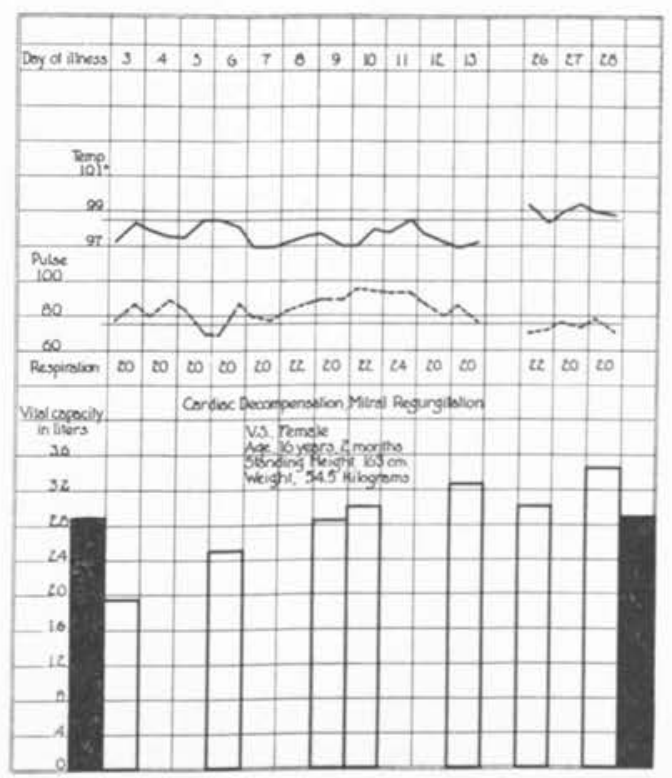

Fig. 6.-Showing the changes in body temperature, pulse rate, rate of respiration and vital capacity of the lungs from the third to the thirteenth and for the twenty-sixth to the twenty-eighth day of illness, for a girls cardiac decompensation, and mitral regurgitation. The solid black rectangles represent the normal vital capacity for corresponding standing height; the blank rectangles represent the observed vital capacity on successive days. 
ment of the vital capacity, therefore, affords a simple and practical method of detecting fluctuations in the general condition of the patient.

This study of a limited number of children suffering from disease of the mitral valve shows that in milder cases in which the vital capacity is practically normal very little respiratory discomfort is experienced even on severe exertion. In more severe cases, however, the tendency to develop dyspnea in a measure parallels the reduction in vital capacity. ${ }^{*}$

7. Vital Capacity and Acute Bronchitis.-In Table 14 are recorded the average vital capacities for seventeen boys and fourteen girls, respectively, having acute bronchitis, which shows that the vital capacity is considerably reduced by this condition. The individual data show the degree of reduction to be rather marked in the more severe cases. Often the presence of considerable mucus in the trachea and bronchi provokes peroxysms of coughing toward the end of expiration, and thus prevent its completion. Even with the patients showing the

Table 14. - Number of Cases, Age, Weight, Standing Height, Vital. Capacity, Normal Vital Capacity for Corresponding Standing Height, and Per Cent. of Deviation from Normal for Boys and Girls Having Acute Bronchitis

\begin{tabular}{|c|c|c|c|c|c|c|}
\hline $\begin{array}{c}\text { Average } \\
\text { Number of } \\
\text { Cases }\end{array}$ & $\begin{array}{c}\text { Average } \\
\text { Age, } \\
\text { Years }\end{array}$ & $\begin{array}{c}\text { Average } \\
\text { Gross } \\
\text { Weight, } \\
\text { Lbs. }\end{array}$ & $\begin{array}{c}\text { Average } \\
\text { Standing } \\
\text { Height, } \\
\text { Cm. }\end{array}$ & $\begin{array}{c}\text { Average } \\
\text { Vital } \\
\text { Capacity, } \\
\text { C.e. }\end{array}$ & $\begin{array}{c}\text { Average } \\
\text { Normal Vital } \\
\text { Capacity } \\
\text { for Cor- } \\
\text { responding } \\
\text { Standing } \\
\text { Height }\end{array}$ & $\begin{array}{c}\text { Average } \\
\text { Per Cent. } \\
\text { Deviation } \\
\text { from } \\
\text { Normal }\end{array}$ \\
\hline $\begin{array}{ll}\text { Boys...... } & 17 \\
\text { Girls..... } & 14\end{array}$ & $\begin{array}{l}10 \\
10\end{array}$ & $\begin{array}{l}65.3 \\
63.1\end{array}$ & $\begin{array}{l}131 \\
131\end{array}$ & $\begin{array}{l}1,450 \\
1,354\end{array}$ & $\begin{array}{l}1,795 \\
1,650\end{array}$ & $\begin{array}{l}-18.9 \\
-17.9\end{array}$ \\
\hline
\end{tabular}

greatest reduction in vital capacity due to their bronchitis, there was little complaint of dyspnea. Peabody and Wentworth also record that the vital capacity of the lungs may be considerably reduced following the inception of acute bronchitis.

8. Vital Capacity and Labor Pneumonia.-During the past year vital capacity records were obtained of eleven children during an attack of pneumonia. The data for nine of the children (Table 15) show the vital capacity to be enormously reduced early in the course of the disease. The degree of reduction is greatly out of proportion to the extent of the pneumonic process even with patients not suffering from pleurisy. For example, one boy (Case 1) on the fifth day of illness, although free from pleurisy, was able to expire only 450 c.c., which is about one third the normal expected for corresponding standing height. At the same time, fluroscopic examination demonstrated the pneumonia to be limited to the lower lobe of the right lung. In this instance, although, roughly, one fourth or less of the total lung tissue was involved by the pneumonic process, nevertheless, the vital capacity 
wats reduced by three fourths. In other cases the reduction is equally striking. The general weakness of the patient is evidently a factor in reducing the vital capacity.

The initial reduction in vital capacity, and its gradual return to normal following recovery from lobar pneumonia is clearly shown for two boys in Figures 7 and 8. In the case of the older patient (Fig. 7), on the second day of illness the vital capacity was reduced 35 per cent. At this time the clinical diagnosis was somewhat uncertain. On the fourth day, however, a diagnosis of lobar pneumonia was definitely established, and the vital capacity was now reduced approximately 71 per cent. Following the crisis the vital capacity gradually

TABle 15.-Number of Cases, Age, Standing Height, Weight, Initial Vital Capacity, Day of Illness, Vital. Capacity at Each Succeeding Reading, Normal Vital Capacity for Corresponding Standing Height, Per Cent. of Deviation from the Normal for Boys and Girls with Lobar PNeumonia

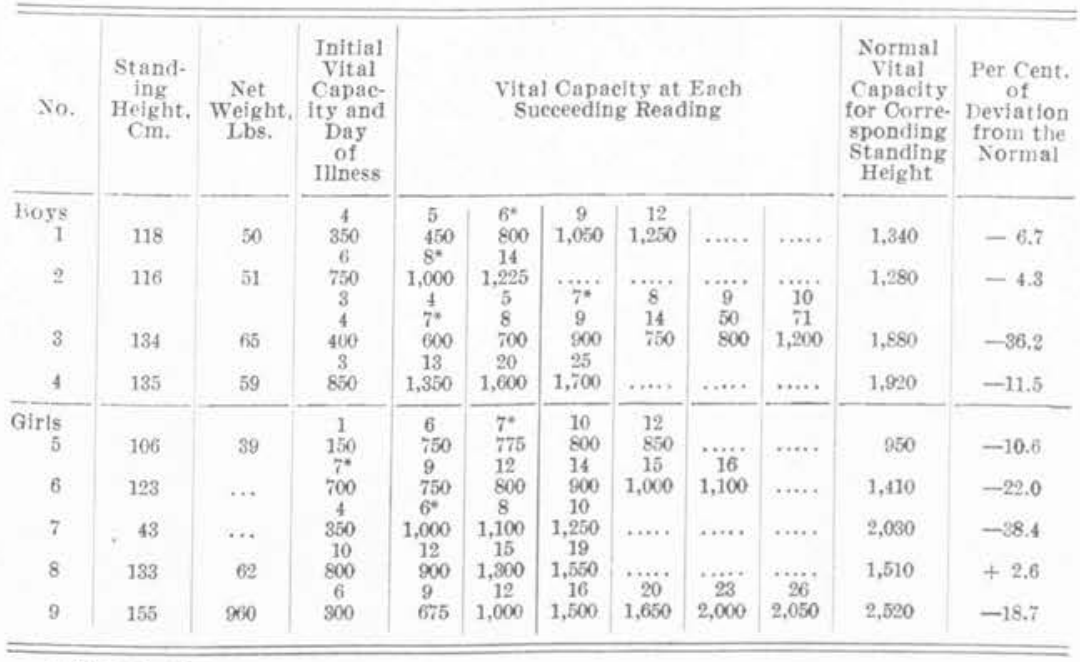

\footnotetext{
- Day of crisis.
}

increased and by the seventeenth day of illness was only slightly more than 17 per cent. below the normal expected for corresponding standing height. For this patient a record of vital capacity was obtained nine months following his recovery from pneumonia. During this interval the records show an increase in vital capacity from 2,850 c.c. to 3,500 c.c. This indicates that following recovery from an attack of pneumonia, subsequent growth in lung capacity may proceed in a rather satisfactory manner.

One child (Case 3 ) failed to recover promptly. Areas of consolidation persisted in one lung for a long time which, finally, terminated in an empyema. The records show that during the period studied the 


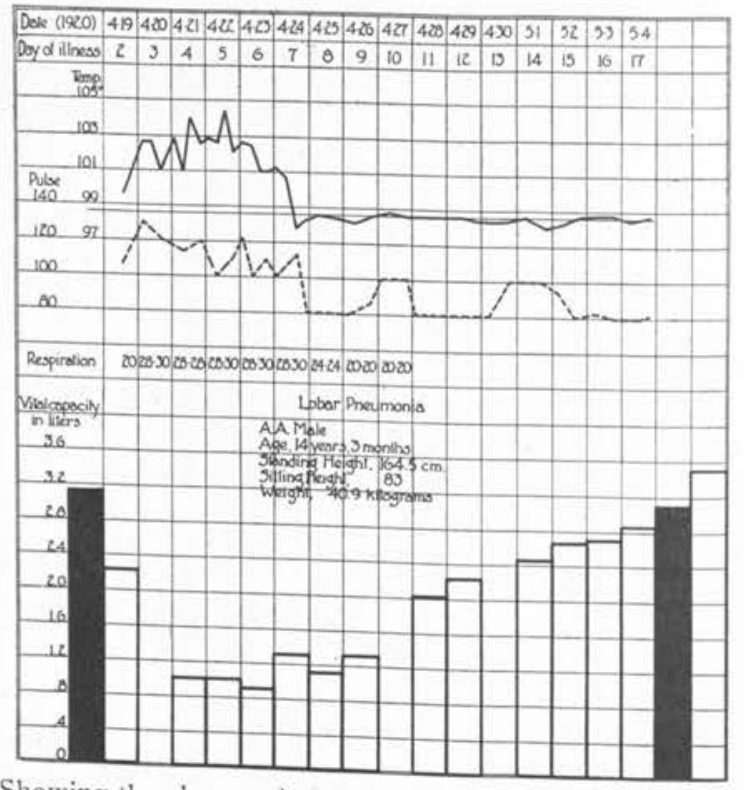

Fig. 7.- Showing the changes in body temperature, pulse rate, rate of respiration and the vital capacity of the lungs from the second to the seventeenth days of illness, for a boy having lobar pneumonia. The solid black rectangles blank rectangles represent capacity for corresponding standing height; the blank rectangles represent the observed vital capacity on successive days.

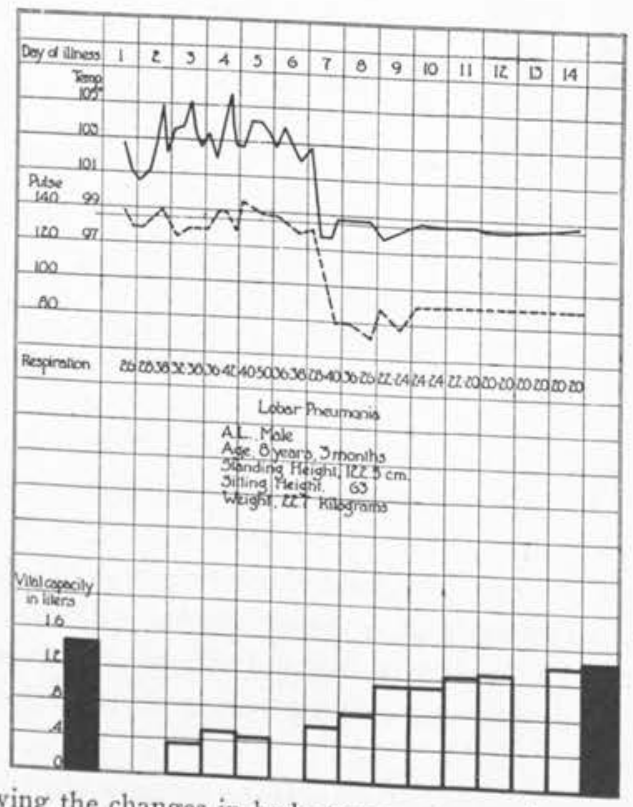

Fig. 8.-Showing the changes in body temperature, pulse rate, rate of respiraof illness, for vital capacity of the lungs from the first to the fourteenth day rof a body having lobar pneumonia. represent the normal vital capacity for corresia. The solid black rectangles rectangles represent the observed for corresponding standing height; the blank 
vital capacity remained considerably below normal. Accompanying slight improvements in the patient's general condition, the vital capacity increased slightly, but decreased again when he felt worse. At the time the last observation was made the vital capacity was still 36 per cent. below the expected normal.

During the course of this investigation the disappearance of physical signs was observed in several instances to precede the complete return of vital capacity to normal.

9. Vital Capacity and Bronchial Asthma.-Several patients subject to attacks of asthma visited the dispensary during the past winter. The

TAble 16. - Number of Cases, Age, Weight, Standing Height, Vital

Capacity, Normal Vital Capacity for Corresponding Standing Height, Per Cent. of Deviation from Normal and Clinical Notes For Boys and Girls Subject to Bronchial Asthma

\begin{tabular}{|c|c|c|c|c|c|c|c|}
\hline $\begin{array}{l}\text { No. of } \\
\text { Cases }\end{array}$ & $\begin{array}{l}\text { Age, } \\
\text { Years }\end{array}$ & $\begin{array}{l}\text { Gross } \\
\text { Weight, } \\
\text { Lbs. }\end{array}$ & $\begin{array}{c}\text { Stand- } \\
\text { ing } \\
\text { Height, } \\
\text { Cm. }\end{array}$ & $\begin{array}{c}\text { Vital } \\
\text { Capacity, } \\
\text { C.c. }\end{array}$ & $\begin{array}{c}\text { Normal } \\
\text { Vital } \\
\text { Capacity } \\
\text { for Corre } \\
\text { sponding } \\
\text { Standing } \\
\text { Height }\end{array}$ & $\begin{array}{l}\text { Per Cent. } \\
\text { of } \\
\text { Deviation } \\
\text { from } \\
\text { Normal }\end{array}$ & $\begin{array}{l}\text { Clinfeal Notes: } \\
\text { Duration of Disease }\end{array}$ \\
\hline \multicolumn{8}{|l|}{ Boys } \\
\hline & 6 & 32 & 109 & 750 & 1,080 & -30.6 & Many râles present \\
\hline 2 & 6 & 39 & 113 & 75 & 1,190 & -34.9 & Many ráles present \\
\hline 3 & 6 & 45 & 118 & 1,600 & 1,340 & +19.4 & \\
\hline $\begin{array}{l}4 \\
0\end{array}$ & $\begin{array}{l}6 \\
8\end{array}$ & $\begin{array}{l}41 \\
48\end{array}$ & $\begin{array}{l}118 \\
123\end{array}$ & $\begin{array}{l}1,550 \\
1,900\end{array}$ & $\begin{array}{l}1,340 \\
1,500\end{array}$ & $\begin{array}{l}+15.7 \\
+26.7\end{array}$ & $\begin{array}{l}\text { No ráles present } \\
\text { No râles present; asthma }\end{array}$ \\
\hline 6 & 7 & 48 & 123 & 1,450 & 1,500 & -3.3 & $\begin{array}{l}\text { for } 6 \text { years } \\
\text { Few rales present; asthma } \\
\text { for } 4 \text { years }\end{array}$ \\
\hline 7 & 8 & 57 & 124 & 800 & 1,530 & -47.7 & Many râles present \\
\hline 8 & 10 & 64 & 132 & 1,900 & 1,810 & +5.0 & $\begin{array}{l}\text { Asthma for } 3 \text { years; no râles } \\
\text { present }\end{array}$ \\
\hline 9 & 11 & 64 & 132 & 1,800 & 1,810 & -0.5 & \\
\hline 10 & 12 & 68 & 140 & 2,350 & 2,100 & +11.9 & $\begin{array}{l}\text { Few râles present; asthma } \\
\text { for } 4 \text { years }\end{array}$ \\
\hline 11 & 13 & 63 & 145 & 2,350 & 2,300 & +2.2 & Asthima for 9 years \\
\hline 12 & 11 & 72 & 146 & 1,950 & 2,340 & -16.7 & $\begin{array}{l}\text { Asthma for } 2 \text { years; no râles } \\
\text { present }\end{array}$ \\
\hline 13 & 14 & 104 & 155 & 3,200 & 2,760 & +15.9 & Eight years \\
\hline \multicolumn{8}{|l|}{ Girls } \\
\hline 1 & 7 & 38 & & 800 & 1,300 & -30.8 & Many râles present; 3 years \\
\hline 2 & 9 & 46 & 120 & 1,275 & 1,380 & -4.1 & No râles present \\
\hline$\frac{3}{4}$ & 9 & 50 & 130 & 1,800 & 1,620 & +11.1 & Few râles present \\
\hline 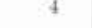 & 13 & 65 & $\cdots$ & 2,500 & ..... & ....... & No rales present; 7 years \\
\hline
\end{tabular}

vital capacity records for these children are tabulated in Table 16 . The data show that the vital capacity, even with children who have experienced severe asthmatic attacks for several years, may be practically normal during intervals when they are free from symptoms. However, immediately following acute attacks, when the lungs show marked evidence of the disease, the vital capacity may be reduced greatly (Cases 1, 2, 7 and 14). The greatest reduction noted in this study amounted to 47.7 per cent. in Case 7. For one patient (Case 2) the vital capacity was recorded during an acute attack, and also again at a later time when he was free from symptoms. In this instance, 
during the attack, his vital capacity was nearly 35 per cent. below normal, whereas after the symptoms disappeared it actually exceeded the normal expected for his standing height almost 12 per cent.

From this study of a limited number of cases the conclusion seems justified that while bronchial asthma may cause an enormous reduction in the vital capacity immediately following an acute attack, nevertheless, the reduction promptly disappears and the vital capacity returns to normal as the symptoms subside. Even in cases subject to the disease for several years there is apparently no permanent reduction in vital capacity.

Peabody and Wentworth note that with adults the vital capacity becomes greatly lowered during asthmatic attacks. Four patients tested soon after acute attacks were found to have vital capacities of 56,60 , 85 and 102 per cent. of the normal, respectively. Seven observations on six patients made when they were in their best condition between

table 17. - Age, Number of Cases, Net Weight, Standing Height, Vital Capacity, Normal Vital Capacity for Corresponding Standing Height, and Per Cent. That Observed Vital Capacity Deviated from the Normal, for Children of Fresh Air School

\begin{tabular}{|c|c|c|c|c|c|c|}
\hline $\begin{array}{c}\text { Average } \\
\text { Age, } \\
\text { Years }\end{array}$ & $\begin{array}{l}\text { Average } \\
\text { Number of } \\
\text { Cases }\end{array}$ & $\begin{array}{c}\text { Average } \\
\text { Weight, } \\
\text { Kg. }\end{array}$ & $\begin{array}{c}\text { Average } \\
\text { Standing } \\
\text { Height, } \\
\text { Cm. }\end{array}$ & $\begin{array}{l}\text { Average } \\
\text { Vital } \\
\text { Capacity, } \\
\text { O.c. }\end{array}$ & $\begin{array}{l}\text { Average } \\
\text { Normal Vital } \\
\text { Oapacity } \\
\text { for Cor- } \\
\text { responding } \\
\text { Standing } \\
\text { Helght, O.e. }\end{array}$ & $\begin{array}{c}\text { Average } \\
\text { per Cent. } \\
\text { Deviation } \\
\text { from } \\
\text { Normal }\end{array}$ \\
\hline $\begin{array}{l}\text { Boys..... } 11 \\
\text { Girls..... } 11\end{array}$ & $\begin{array}{l}46 \\
51\end{array}$ & $\begin{array}{l}33.0 \\
32.3\end{array}$ & $\begin{array}{l}142.8 \\
140.0\end{array}$ & $\begin{array}{l}2,055 \\
1,842\end{array}$ & $\begin{array}{l}2,182 \\
1,925\end{array}$ & $\begin{array}{l}-5.8 \\
-4.3\end{array}$ \\
\hline
\end{tabular}

asthmatic spells showed a range in vital capacity between 65 and 122 per cent. of the normal. In only one case was it below 85 per cent.

10. Vital Capacity and Tuberculosis.-In Table 17 are recorded the vital capacities of forty-six boys and fifty-one girls, all of whom were attending what is known as the fresh air school. Children are eligible for admission to this school only in case they have a positive Pirquet (tuberculin) reaction, and show some clinical evidence of tuberculosis, such as slight daily elevation in temperature, frequent attacks of bronchitis or failure to gain in weight properly. Physical examination of the lungs in most instances was practically negative, except for the usual presence of a positive D'Espine sign, and, as a rule, the roentgenray findings were limited to enlarged peribronchial lymph glands at the hilus of the lungs. The condition of this group of cases is probably fairly representative of the usual early type of quiescent tuberculosis encountered in children.

The vital capacity of the lungs for the boys (Table 17), while tending to be slightly low in many cases, in general, agrees fairly well 
with normal averages for corresponding height. The reading for only five of the boys appeared to be definitely subnormal. However, on comparing the stem length of each of these boys with the normal as found by Boas ${ }^{26}$ for corresponding height, in each instance the observed sitting height is found to be considerably less than that expected of boys of their height. Since standing height seemed rather abnormal with these boys as compared with their sitting height, it was thought that the records would probably agree more closely with averages of vital capacity based on stem length. When the observed vital capacities was compared with the normal expected for corresponding stem length in each instance, the vital capacity appears to be practically normal as compared with the normal for corresponding sitting height. In general, then, it is doubtful if the lung capacity of any of these forty-six boys can be considered as definitely abnormal in this respect.

For the girls (Table 17) the average vital capacity agrees fairly well with the normal expected for corresponding standing height. In only four instances were the readings significantly subnormal.

While the number of observations is too small to permit of very sweeping conclusions, nevertheless, the data indicate that the vital capacity is usually normal in children reacting positively to the intracutaneous application of old tuberculin and showing little additional evidence of tuberculosis aside from a positive D'Espine and a comparatively poor health record. Certain of these children, however, have an abnormally low vital capacity. These may be the ones who are most likely to develop serious forms of the disease in the future. Later determinations of their vital capacity, if showing a further decrease, would probably give immediate clue to any change in their pulmonary condition.

In addition to these children showing a minimum evidence of tuberculosis, the lung capacity also of twenty-six boys and seventeen girls with definite tuberculosis of bone was studied. The data obtained from this series of patients are recorded in Table 18. The average value for the readings for each sex appear to be practically normal for standing height. For a few of the individuals, however, the lung capacity was abnormally low, especially with the more serious cases. For one boy the reduction amounted to 40 per cent. This boy has a marked kyphosis of the midthoracic region which is completely ankylosed. The marked deformity and resultant mechanical interference with inspiration probably accounts partly for his low vital capacity, especially since the lungs are apparently normal.

For another patient the vital capacity was 46.4 per cent. below the normal expected. This patient was in a very poor general condition,

26. Boas, F., and Wissler, C.: Statistics of Growth, U. S. Education Commision 1, 1904. 
weighing only 49 pounds, and has an active tuberculosis of the lower lumbar spine with a psoas abscess and several discharging sinuses. The roentgen ray also revealed a marked shadow about the hilus and considerable mottling throughout the lung field. Six months later the vital capacity was recorded a second time and during this period was found to have decreased from 1,050 c.c. to 750 c.c., a decrease of about 29 per cent. At this time his condition was definitely worse than at the previous examination. In this instance one, no doubt, would

Table 18. - Number of Cases, Age, Weight, Standing Height, Vital Capacity, Normal Vital Capacity for Corresponding Standing Height, Location and Extent of Disease for Boys Having TuberCUlosis of BONE AND LUNGS

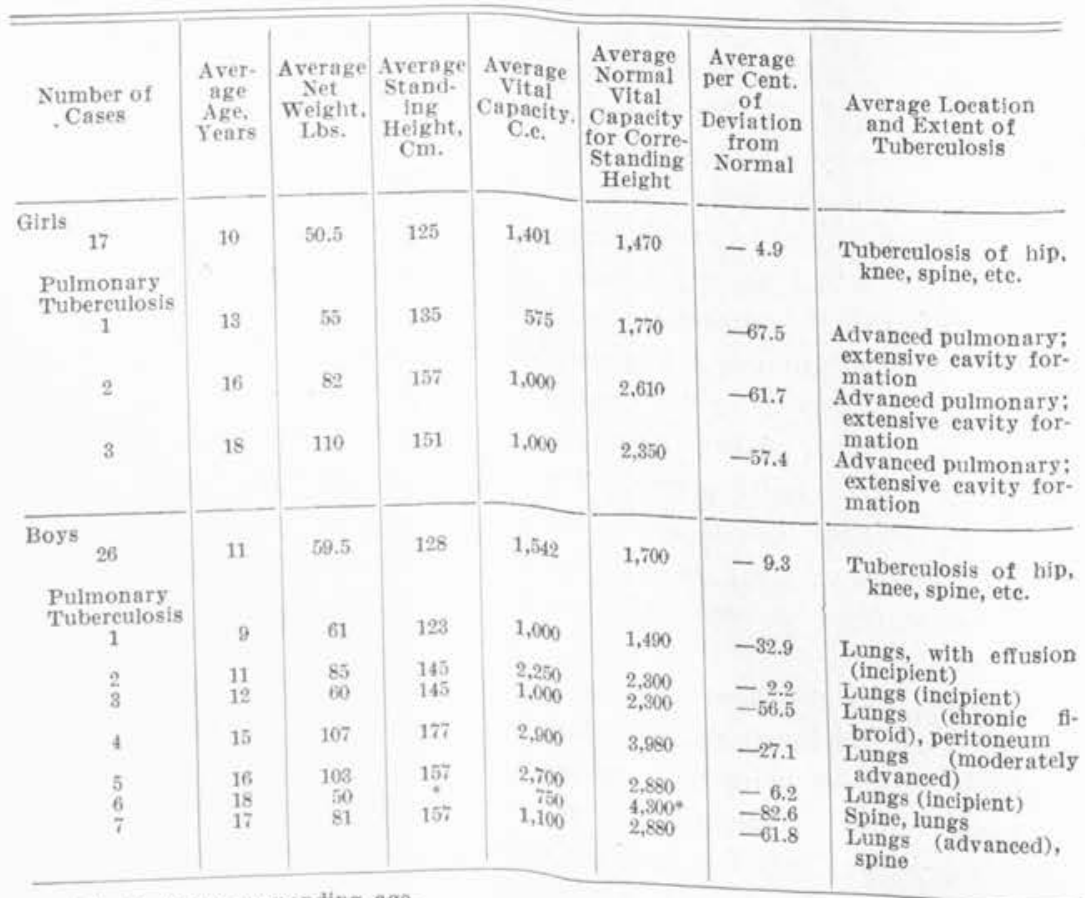

- v. C. for corresponding age.

suspect the above to be true merely from considering the vital capacity record alone, even without knowing other facts about the case.

For the seventeen girls (Table 18) having tuberculosis of the bone the average for the vital capacity is practically normal. The volumes for two subjects of this group, however, were abnormally low, being 25.6 and 35.5 per cent., respectively, below the normal for corresponding height. With these two girls observations six months later show in each instance an increase of about 100 c.c., in vital capacity.
The gain in lung capacity registered by these patients during this period 
probably indicates a better prognosis than in the case mentioned above in which the vital capacity decreased to a considerable extent.

In only a few instances was it possible to obtain observations of the vital capacity of the lungs of children with definite and active pulmonary tuberculosis. Data for ten such cases are recorded in Table 18. Of the incipient cases only one boy (Case 1) has a vital capacity significantly subnormal. In this instance the presence of a pleural effusion probably accounts for a considerable portion of this reduction. In Case 2 the lung capacity is practically normal. The roentgenogram of this patient's lungs revealed a rather large shadow extending from the hilus out into the parenchyma of the right lung; and the Pirquet reaction was strongly positive. About one months after the vital capacity was recorded for the first time, this boy had a tonsillectomy following which he developed a tuberculous meningitis and promptly died. This case illustrates, therefore, that a normal vital capacity may be obtained even in the presence of a pathological pulmonary condition of the most serious potentialities.

Among the advanced cases, two patients (Cases 3 and 9) have died during the past few months. In these cases, however, death was not unexpected for in both the tuberculous process was very extensive. It is interesting to note that of the advanced cases four patients (Cases $6,7,8$ and 9) were ambulatory and suffered no dyspnea on mild exertion in spite of the fact that their vital capacities were reduced to about one third their normal value. This observation stands out in marked contrast to these symptoms noted in cardiac disease for with a similar reduction in vital capacity dependent on some pathologic condition of the heart, dyspnea is a constant and very prominent symptom.

Many investigators, including Hutchinson, Wintrich, Scheevoogt, Arnold, Fabius, Schönfeld, ${ }^{27}$ Siebeck, Wilson and Edwards, and others, have observed that the vital capacity may be reduced greatly in the presence of pulmonary tuberculosis. Recently Dreyer and Burrell ${ }^{20}$ have been able to classify cases of pulmonary tuberculosis as normal or as incipient, moderate or advanced, without seeing the patients, knowing only their vital capacity and various body measurements.

From a study of patients with incipient tuberculosis Garvin, Lundsgaard and Van Slyke ${ }^{28}$ found the vital capacity to be reduced as a result of an increased residual air. In moderately advanced and advanced cases the vital capacity was substantially reduced principally

27. Schonfeld, L.: Ein Beitrag zur Lehre von der Spirometrie, Diss. Berlin 1882.

28. Garvin, A.; Lundsgaard, C.; Van Slyke, D. D.: Studies of Lung Volume II Tuberculous Men, J. Exper. M. 27:87, 1918. Studies' of Lung Volume III, Tuberculos Women, J. Exper. M. 27:129, 1918. 
as a result of diminished total lung capacity. The residual air was normal, as a rule, although in a few cases an increase in residual air also contributed to the decrease in vital capacity.

Wittich, Meyers and Jennings ${ }^{29}$ found the vital capacity to decrease relative to body weight, in direct proportion to the amount of disease present.

\section{CONCLUSIONS}

From this study it appears evident that the determination of the vital capacity of patients having diseases of the heart and lungs is of distinct clinical value. Although single observations are of importance, repeated measurements are of much greater value, for changes in the pathologic condition of these organs is immediately reflected by fluctuations in the vital capacity. It is undoubtedly inadvisable to use the determination of the vital capacity to the exclusion of other means of making a diagnosis, for occasionally this measurement is very misleading, and might easily lead to serious error if relied on alone. However, with the exercise of proper judgment and care, one usually is able to use the information gained through the measurement of the vital capacity safely and profitably in determining not only the presence but also roughly the extent and progress of the disease of the heart and lungs.

\section{SUMMARY}

The more important results of the present investigation may be summarized briefly as follows:

1. At either corresponding age, standing height, sitting height, or body weight the vital capacity of the lungs is constantly greater with the boys than with the girls, the difference increasing with the especial rapidity during the latter half of childhood. ${ }^{30}$

2. The curves of vital capacity as plotted against age, standing and sitting height, in general, pursue a sinuous course, showing a fairly uniform increase at first, followed later by a period of more rapid growth in lung capacity, which later diminishes in rate. The curve plotted against body weight-for the boys shows a more uniform course, while that for the girls has a definitely convex form.

3. The absolute annual increase in vital capacity, in general, is fairly uniform during early childhood, increases in rapidity about the time of puberty, and later declines.

4. The relative increase in vital capacity apparently decreases at first, becomes relatively more rapid about the time of puberty, and

29. Wittich, F. W., Myers, J. A., and Jennings, F. L.: A Study of the Effect of Pulmonary Tuberculosis on Vital Capacity, J. A. M. A. 75:1249 (Nov. 6) 1920.

30. Emerson, P. W., and Green, H.: Vital Capacity of the Lungs of Children, Am. J. Dis. Child. 22:202 (Aug.) 1921. 
then proceeds at a slower rate again. The period of acceleration in the rate of growth in lung capacity begins and terminates at an earlier age with the girls than with the boys.

5. Throughout childhood the vital capacity formed a greater proportion of the estimated adult maximum (3,200 c.c.) for women with the girls, than with the boys, the adult maximum of the latter be estimated as approximately 4,300 c.c. In general, then, with respect to lung capacity, at corresponding ages the girls may be considered relatively more mature than the boys.

6. The vital capacity of the lungs apparently reaches a maximum near the twentieth year with the boys, and probably slightly before this time with the girls.

7. On using the proper values for the constant, the vital capacity may be computed ${ }^{31}$ fairly accurately from the age, the standing height, the sitting height or the body weight by means of the empirical fornula $y=(\mathrm{AX}) \pm b$, where $y=$ vital capacity in cubic centimeters; $a=$ (either age in years, standing height or sitting height in cubic centimeters or body weight in pounds), $\mathrm{X}=\mathrm{a}$ constant, and $\pm b=\mathrm{a}$ second constant. The proper values for the constants may be determined by referring to the appropriate tables.

8. The probable error of random sampling increases as the vital capacity increases, but in all instances is relatively small, amounting to less than 25 c.c., as a rule. Therefore, averages obtained from an infinitely large number of comparable series would vary only slightly from those obtained in the present limited series of observations.

9. The standard deviation (absolute variability), as a rule, increases as the vital capacity increases, and usually is greater with the boys than with the girls of corresponding age and size.

10. The coefficient of variation (relative variability) for each sex decreases during early childhood, increases about the period of puberty and later declines again. The extent of the dispersal of the individual observations from the averages, appears to be smaller when averaged in groups differing $5 \mathrm{~cm}$. in standing height or $2 \mathrm{~cm}$. in stem length, than when averaged according to age in years, as estimated from the nearest birth day.

11. The constant relation between the vital capacity and the square of the sitting height, and also between the 0.72 power of the body weight in grams and the vital capacity apparently is not established until the latter part of childhood.

12. Children may have a normal vital capacity even in the presence of a definite insufficiency of the mitral valves, and these individuals show

31. West, H. F.: Clinical Studies on the Respiration. VI. A Comparison of Various Standards for the Normal Vital Capacity of the Lungs, Arch. Int. Med. 25:306 (March) 1920. 
little abnormal tendency to dyspnea on exertion. In more serious cases the vital capacity is greatly reduced, and the tendency to respiratory embarrassment is proportional to the reduction in lung capacity. ${ }^{32}$

13. When the condition of the heart improves, the vital capacity gradually increases.

14. Acute bronchitis produces a temporary reduction in vital capacity, which in severe cases may be very marked.

15. During the course of lobar pneumonia the vital capacity rapidly undergoes an enormous reduction, even in cases free from pleurisy. The reduction is altogether out of proportion to the extent of the pneumonic process in the lungs. Following the crisis, the vital capacity gradually returns to normal, in a comparatively short time. Physical signs of the disease, however, may disappear before the normal vital capacity is reached. In complicated cases the return of vital capacity to normal may be greatly delayed.

16. While bronchial asthma may cause an enormous reduction in the vital capacity immediately following an acute attack, nevertheless the reduction promptly disappears as the symptoms subside. Even in children subject to the disease for several years, there is apparently no permanent reduction in the vital capacity of the lungs.

17. With children showing slight evidence of tuberculosis, such as a positive Pirquet (tuberculin) reaction, and having a poor health record, and also with those having definite tuberculosis of bone, the vital capacity is normal, as a rule. In a few instances, however, the lung capacity is sufficiently subnormal to lead one to suspect some pulmonary involvement.

In incipient pulmonary tuberculosis the vital capacity may be practically normal, even in the presence of a very active and virulent infection in the lungs.

In advanced pulmonary tuberculosis the vital capacity of the lungs is greatly reduced, in proportion to the extent of the disease process.

18. The abnormal tendency to dyspnea on exertion is much more marked when the reduced vital capacity is caused by disease of the heart, than when caused by disease of the lungs alone, even in instances where the reductions are similar in extent.

32. Pearce, R. G.: The Cardiorespiratory Mechanism in Health and Disease, Arch. Int. Med. 27:139 (Feb.) 1921.

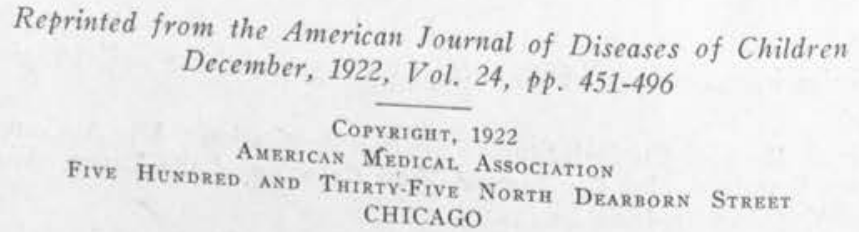

